\title{
CORPO, COMPORTAMENTO E CONSUMO: AS MULHERES DO MOVIMENTO FEMINISTA E AS MULHERES DOS ANÚNCIOS DE LINGERIE
}

\author{
DASCALE MULLER \\ Universidade Federal do Paraná \\ Curitiba, Paraná \\ E-mail: dascale_muller@hotmail.com. \\ CARLA CANDIDA RIZZOTTO \\ Universidade Federal do Paraná \\ E-mail:carla_rizzotto@yahoo.com.br.
}


Resumo: Algumas das principais lutas do movimento feminista giram em torno da representação da mulher, na família, no mercado de trabalho, na política e na mídia. Todavia, a mulher ainda é estereotipada e o culto ao corpo continua sendo incentivado pela publicidade. A partir desta observação inicial, é objetivo deste artigo traçar um paralelo entre a evolução histórica do movimento feminista e a evolução na representação da mulher em anúncios de lingerie ao longo das décadas.

Palavras chave: Movimento feminista; Publicidade; Representação da mulher.

BODY, BEHAVIOR AND CONSUMPTION: WOMEN OF THE FEMINIST MOVEMENT AND WOMEN OF THE LINGERIE ADS

\begin{abstract}
Some of the major struggles of the feminist movement revolve around the women representation in the family, the labor market, in politics and in the media. However, women are still stereotyped and body worship continues to be encouraged by advertising. From this initial observation the purpose of this article is to draw a parallel between the historical evolution of the feminist movement and the developments in the representation of women in lingerie ads over the decades.

Keywords: Feminist movement; Advertising; Women representation.

\section{CUERPO, COMPORTAMIENTO Y CONSUMO: LAS MUJERES DEL MOVIMIENTO FEMINISTA Y LAS MUJERES DE LOS ANUNCIOS DE ROPA INTERIOR}

Resumen: Algunas de las principales luchas del movimiento feminista giran en torno a la representación de la mujer en la familia, en el mercado de trabajo, en la política y en los medios de comunicación. Sin embargo, las mujeres siguen siendo estereotipados y el culto al cuerpo sigue siendo alentado por la publicidad. A partir de esta observación inicial el propósito de este artículo es establecer un paralelismo entre la evolución histórica del movimiento feminista y la evolución en la representación de las mujeres en los anuncios de ropa interior sobre las décadas.

Palabras clave: Movimiento feminista; Publicidad; Representación de la mujer. 


\section{INTRODUÇÃO}

Ao longo dos anos, a humanidade passou por diversas mudanças e processos que resultaram na sociedade em que vivemos hoje. Seja no universo político ou cultural, a configuração atual destes cenários tem contribuição de diversos sujeitos, coletivos e grupos que, de forma pacífica ou não, buscaram mudar a ordem estabelecida fazendo valer suas reivindicações.

O feminismo é um exemplo de movimento que, utilizando de diversas formas de manifestação, contribui com uma mudança no posicionamento da mulher na sociedade. Essa mudança representou não só transformações na política, mas também na instituição familiar. Muitas conquistas do movimento feminista giram em torno da representação da mulher, seja na família, no mercado de trabalho, na política ou na mídia.

É necessário pontuar que após muitas décadas de luta em busca dos direitos de igualdade de gêneros, o movimento feminista encontra ainda obstáculos e motivações para continuar presente e cada vez mais relevante na esfera pública. Questões como abuso sexual, disparidades no mercado de trabalho, liberdade sexual e a representação da mulher na mídia são extremamente atuais. O modo como a mulher é representada na mídia e na publicidade não está necessariamente alinhado com as tendências de luta pela igualdade de gêneros. Diante disso, coloca-se o problema deste artigo: como a publicidade representa o corpo e o comportamento femininos e como esta representação se relaciona com a imagem e papel social da muIher. Pretende-se verificar até que ponto o sentido simbólico apresentado pela publicidade acompanha a evolução das discussões feministas acerca da representação da mulher. Assim, esta pesquisa tem como objetivo geral traçar um paralelo entre o histórico do movimento feminista e a representação do feminino na publicidade de moda íntima.

A metodologia consistiu em uma análise de conteúdo da amostra selecionada de dez anúncios de cada década - desde a década de 1970, período que marca o início da segunda onda do feminismo, na qual começou a ser questionada a influência da cultura na imagem e na definição de gêneros, até os dias atuais. Foram criadas categorias que exploram as questões de representação da mulher na publicidade: os referenciais comportamentais, a direção do sentido da publicidade e as características semióticas do anúncio. 


\section{O MOVIMENTO FEMINISTA NO BRASIL}

A insatisfação das mulheres nas primeiras décadas do século XX girou em torno da questão dos direitos políticos, principalmente do voto. Na república oligárquica, famílias com muitas posses conseguiam que seus filhos estudassem em universidades e desenvolvessem suas mentes em um cenário além-fronteiras. Nestas famílias, surgiram as principais personagens do feminismo: "Não havia nessas famílias condutas éticas diversas ou formas alternativas de pensar o papel da mulher, mas um ambiente distinto que possibilitou às filhas o acesso ao mundo culto da leitura e da valorização da educação" (PINTO, 2003, p.17). Neste cenário foi fundado o Partido Republicano Feminino por Leonilda Daltro e Gilka Machado, em 1910. O objetivo do partido direcionava-se às lutas pelo direito ao voto e pela emancipação da mulher brasileira. Um dos marcos do enfrentamento contra os princípios vigentes na sociedade foi, em 1917, a marcha de 90 mulheres pelas ruas do Rio de Janeiro. Este momento chamou a atenção da imprensa carioca para a reivindicação dos direitos constitucionais por parte do partido. A partir daí, o movimento passou a ser discutido na esfera pública.

Os primeiros momentos do feminismo no Brasil caracterizaram-se pela presença de mulheres elitizadas e com referencial cultural ímpar em relação à maioria da população feminina. Jornalistas, engenheiras, médicas, advogadas, entre outras, compuseram o que Céli Pinto denomina de feminismo "bem-comportado" - uma fase consideravelmente conservadora, que não questionava as relações de gênero e opressão, mas que buscava exclusivamente a inclusão da mulher na cidadania (PINTO, 2003).

Ainda nesta fase, a autora identifica o feminismo "malcomportado", que abordava mais fortemente as relações entre os gêneros, questão mais polêmica e profunda para a época. $O$ ideário anarquista, introduzido por imigrantes que trabalharam em indústrias, e o comunismo, inspiraram movimentos de caráter libertário pelo feminismo, que se distanciou das questões políticas. A principal personagem desta fase é Maria Lacerda de Moura (BUITONI, 1981).

Os movimentos que surgiram até a década de 30 foram, sem dúvidas, evidências de que a sociedade começava a se organizar pela busca dos seus direitos frente ao poder oligárquico: 
suas ideias e demandas. E as mulheres, sem dúvida, faziam parte desse movimento, quer fossem da elite ou da classe operária (PINTO, 2003, p. 39).

Em 1937, o Golpe do Estado Novo, que garantiu a presença de Getúlio Vargas no poder, mudou completamente o cenário político. Desde então e até meados de 1970 o movimento feminista passou por um período quase que silencioso. Após um período de incubação do movimento, eclodem a partir dos anos 60 novas formas de manifestação de caráter mais resistente. Na América do Norte e na Europa, o período antecedente foi marcado por instabilidade econômica e política pós-guerra e, consequentemente, diversos grupos descontentes com os ideários de felicidade e modo de vida impostos pela classe dominante começaram a buscar espaço para expressão. $\mathrm{Na}$ América Latina, especialmente no Brasil, o movimento feminista ressurgiu com a influência das tendências internacionais de resistência, principalmente a favor do fim das diferenças sociais relacionadas ao gênero, e teve foco nas lutas contra a ditadura militar.

\footnotetext{
Embora uma confluência de fatores tenha contribuído para a eclosão do feminismo brasileiro nos anos 70 - como o impacto do feminismo internacional e mudanças efetivas na situação da mulher no país a partir dos anos 60, que punham em questão a tradicional hierarquia de gênero -, o feminismo no Brasil surge como consequência da resistência das mulheres à ditadura militar, depois da derrota da luta armada e no sentido da elaboração política e pessoal desta derrota (SARTI, 1998, p.3).
}

Os anos 80 foram marcados pela redemocratização do país e pela anistia dos presos políticos da ditadura. Esta fase representava "maior libertação, menos medo e mais possibilidades de manifestação" (PINTO, 2003, p. 67). Apesar de ainda estar sob o poderio militar, o país já não era refém dos atos de censura característicos da década anterior, que criou espaços para a oposição manifestar-se politica e ideologicamente. Para o movimento feminista, esta década representou mudanças no seu curso: as representantes dividiram-se entre o PMDB (Partido do Movimento Democrático Brasileiro) e o PT (Partido dos Trabalhadores), definindo vertentes que procuravam se aproximar da esfera estatal, afastando a ideia de um movimento autônomo.

Neste período, o movimento feminista também começou a adquirir espaço acadêmico, com estudos no Departamento de Pesquisa da Fundação Carlos Chagas, em São Paulo, e a criação de Núcleos de Pesquisa em Estudos da Mulher em diversas universidades (PINTO, 2003). 
Um avanço significativo das inquietações do movimento foi a criação das Delegacias da Mulher, em 1985, que reconheceu publicamente que a mulher era vítima de violência. Ainda neste período foram criados os Conselhos de Condição da Mulher, derivado das mobilizações das Diretas-Já em 1983, marcou a reunião das frentes de oposição, instituiu o Movimento de Mulheres pelas Diretas-Já e consolidou a institucionalização do movimento. O Conselho Nacional dos Direitos da Mulher, criado por José Sarney após a morte de Tancredo Neves, contava com uma estrutura de ministério e abordava questões que iam desde o direito reprodutivo da mulher até lutas por creches, teve vida curta, contudo (PINTO, 2003).

A Assembleia Constituinte que gerou a Constituição de 1988 contava com a participação de apenas 26 mulheres, que representava 5,7\% do total de representantes. Entretanto, a bancada feminina levou ao congresso, de forma suprapartidária, propostas que englobavam a maioria das reivindicações feministas. Entre os pontos destacavam-se a questão da violência contra a mulher e o aborto, ainda que este último não tenha estado presente na "Proposta à Assembleia Constituinte" enviada pelo Conselho Nacional de Direitos da Mulher. Destaca-se neste período a pressão e participação do movimento feminista no processo constituinte, com expressão inclusive de manifestantes da sociedade civil: "Através de uma ação direta de convencimento dos parlamentares, que ficou identificada na imprensa como o lobby do batom, o movimento feminista conseguiu aprovar em torno de $80 \%$ de suas demandas, se constituindo no setor organizado da sociedade civil que mais vitórias conquistou" (COSTA, 2004, p.7).

A década de 80 representou mudanças significativas no perfil do movimento. A participação política e a institucionalização do movimento, que não existiam nas décadas anteriores, contribuíram para o aumento do número de participantes e para a amplificação das discussões acerca das questões de gênero.

Na década seguinte marcam a história do feminismo no Brasil a difusão do pensamento feminista e a profissionalização por meio das ONGs dedicadas às questões das mulheres. A consciência de protesto contra questões de gênero banalizadas pela sociedade e o caráter mais emergencial das demandas tornaram-se características desse período para os movimentos sociais.

O feminismo já não apresentava uma homogeneidade de demandas sobre a sociedade, mas estava difuso, aparecendo em diversos cenários. Fortaleceu-se principalmente no âmbito popular, em associações de barros, 
sindicatos de operárias, entre outros. Com o objetivo de organizar estes movimentos populares de base, foi criada em 1994 a Articulação da Mulher Brasileira (AMB) que prepararia as militantes para a Conferência Internacional de Beijing de 1995. O ponto principal do encontro era avaliar as mudanças no cenário das condições femininas e chamar atenção sobre a importância de discutir os direitos da mulher em encontros internacionais (COSTA, 2004). O evento de Beijing concentrou suas discussões no acesso da mulher aos meios de comunicação, na sua participação como produtoras de conteúdo, bem como na representação da mulher na mídia (AZNAR apud RIZZOTTO, 2013).

Recentemente, o que se tem observado é a inclusão cada vez maior das demandas do movimento feminista na discussão pública. A luta feminista contemporânea, que tornou-se mais visível devido a sua inserção no ciberespaço, é voltada, principalmente, à exagerada valorização de padrões de beleza e à violência de gênero. Representantes do movimento com vasta visibilidade como Lola Aronovich, do blog Escreva, Lola, escreva; Clara Averbuck, do Lugar de Mulher e Aline Valek, do Ficções de Aline Valek, cumprem o papel de esclarecer as características e os objetivos do movimento feminista. É exemplo o seguinte trecho publicado por Averbuck:

Feminismo não prega ódio, feminismo não prega a dominação das muIheres sobre os homens. Feminismo clama por igualdade, pelo fim da dominação de um gênero sobre outro. Feminismo não é o contrário de machismo. Machismo é um sistema de dominação. Feminismo é uma luta por direitos iguais. [...] Existe essa grande falha lógica que é o sujeito achar que você tem que ser contra uma coisa pra ser a favor de outra; neste caso, "contra" os homens para ser "a favor" das mulheres. O feminismo não luta contra os homens, e sim contra o supracitado sistema de dominação, que, veja só, privilegia os homens e foi criado por... homens. Fica clara a diferença entre lutar contra um sistema e lutar contra todo um gênero?

A influência dessas mulheres, devido à sua inserção no ciberespaço, vem aumentando em diversas camadas da sociedade. Acontecimentos são observados na sociedade e, em questão de horas, já estão sendo discutidos publicamente através das redes sociais. Assim vem se configurando as novas fronteiras da manifestação pública e organização militante, que estão cada vez mais informais, mas cada vez mais representativas. 


\section{A MULHER E A PUBLICIDADE}

Para a análise dos anúncios foram definidas categorias a fim de explorar a relação da publicidade de moda íntima com as representações de corpo e relações de gênero, dando suporte para a análise contextual da propaganda direcionada ao público feminino no decorrer das décadas e para verificação de sua consonância com o discurso social do período.

As peças a serem analisadas foram veiculadas em publicações cujo público alvo são mulheres, das classes A, B e C, entre 18 e 50 anos. $O$ corpus foi selecionado por meio da pesquisa em exemplares físicos e digitais de revistas femininas. Sites das marcas e acervos digitais de publicidade foram as principais fontes de anúncios, principalmente das décadas mais antigas. Problemas como conservação e escassez de exemplares foram agravantes para as publicações mais antigas. Foram coletados 10 anúncios de cada década a partir da década de 70, totalizando 50 anúncios. As categorias que orientarão a análise são as seguintes:

\section{* FUNÇÃo PUBLICITÁRIA: REPRESENTATIVA X CONSTRUTIVA}

Esta categoria visa distinguir os anúncios quanto à sua função discursiva. As peças podem ter um caráter representativo - que irá interpretar a realidade, representar exclusivamente o "sentido já presente" (FLOCH, 2003, p. 210) - ou construtivo, quando utilizam de artifícios para construir um discurso que irá nortear o entendimento, estimulando a interpretação da mensagem. Ao situar as peças entre construtivas ou representativas, poderemos ter uma amostra da intenção dos anunciantes perante seu público-alvo: se ele irá usar argumentos racionais de consumo, como qualidades físicas, material, conforto, etc. ou se irá usar apelos sentimentais, construir um cenário que ocasionará o uso da imaginação por parte do consumidor.

* tipo de publicidade: RefERENCIAL X oblíqua X mítica X SUbStanCial

Depois de analisar a função da publicidade, as peças serão classificadas conforme as quatro categorias propostas por Floch (2003) no quadrado semiótico da publicidade. A partir da análise estrutural - herdada de Saussure - Greimas (1984) desenvolveu o Quadrado Semiótico, que visa categorizar 
as estruturas do objeto semântico de forma dinâmica, através de três relações de sentido: contrariedade, contradição e complementaridade. Aplicando os parâmetros semio-estéticos sobre a publicidade, podemos observar que o discurso é configurado de maneiras específicas. Floch (1993) propôs traçar a relação entre o produto e sua realidade com o discurso publicitário, estabelecendo 4 tipos de publicidade: (1) Publicidade referencial, em que a representação da realidade é evidenciada e situações do cotidiano e a experiência vivida são valorizadas. Tem um caráter imediatista e direto para o consumidor. Anúncios que mostram passo-a-passo, receitas, imagens realistas, demonstrações, são exemplos deste tipo de emprego do discurso; (2) Publicidade oblíqua, em que o sentido deve ser construído, negando o que mostra a publicidade referencial. $O$ consumidor deve interpretar o discurso apresentado, possivelmente utilizar seus elementos cognitivos para ver a mensagem e definir seu sentido, alterar sua percepção sobre um objeto que já é conhecido, agregando valor ao produto em questão; (3) Publicidade mítica, que propõe o consumo como mais que um ato do cotidiano. Aqui o produto comprado traz um desejo, imaginação ou fantasia agregados a si. O valor está diretamente ligado com a história elaborada no discurso, com os elementos utilizados na sua construção (a atmosfera, personagens, cores, sons, etc.) e, (4) Publicidade substancial, que baseia-se na essência do produto e não na atmosfera ou história construída em seu entorno. Valoriza o produto substancialmente, geralmente representado fidedignamente na peça publicitária e chamando mais atenção do que o discurso ou outros elementos.

* direção de Sentido: público-Alvo (FEMinino) x Público-SeCundário (MASCULINO)

Nesta categoria iremos verificar quem é realmente o interlocutor da mensagem publicitária. Baseando-se no texto e na linguagem será possível observar quem realmente era o alvo dos anunciantes para estimular o desejo de compra. Pode-se até estender a discussão para o âmbito da satisfação de desejo do consumidor: a quem o produto deseja agradar? À mulher que irá usá-lo, ou ao parceiro (homem), que não é o consumidor primário da peça? Aqui poderemos discutir os conceitos de imagem pessoal nas relações afetivas e quais os princípios e valores disseminados pela cultura no que se refere ao contraponto entre bem-estar pessoal ou relacionamento afetivo com o parceiro. 
* REPRESENTAÇÃo COMPORTAMENTAL: SeNSUALIDADE X CONFORTO

Analisando o modo como a modelo se posiciona na foto do anúncio, o texto e outros elementos gráficos, iremos verificar se o anúncio irá evidenciar o cunho sexual do produto, ou o conforto que a peça pode proporcionar. Esta categoria irá, assim como a anterior, verificar como são os valores relacionados ao corpo feminino, comportamento e a sexualidade transmitidos pelos meios de comunicação - neste caso, a publicidade - no decorrer das décadas.

\subsection{Década de 70: atributos práticos}

A propaganda na década de 70 mostrou ser bastante heterogênea. Quanto à função publicitária, metade dos anúncios analisados foi classificada como representativa, com características mais expositivas, e a outra metade como construtiva, envolvendo um contexto e artifícios para construção de sentido (Gráfico 1).

\section{Função Publicitária}

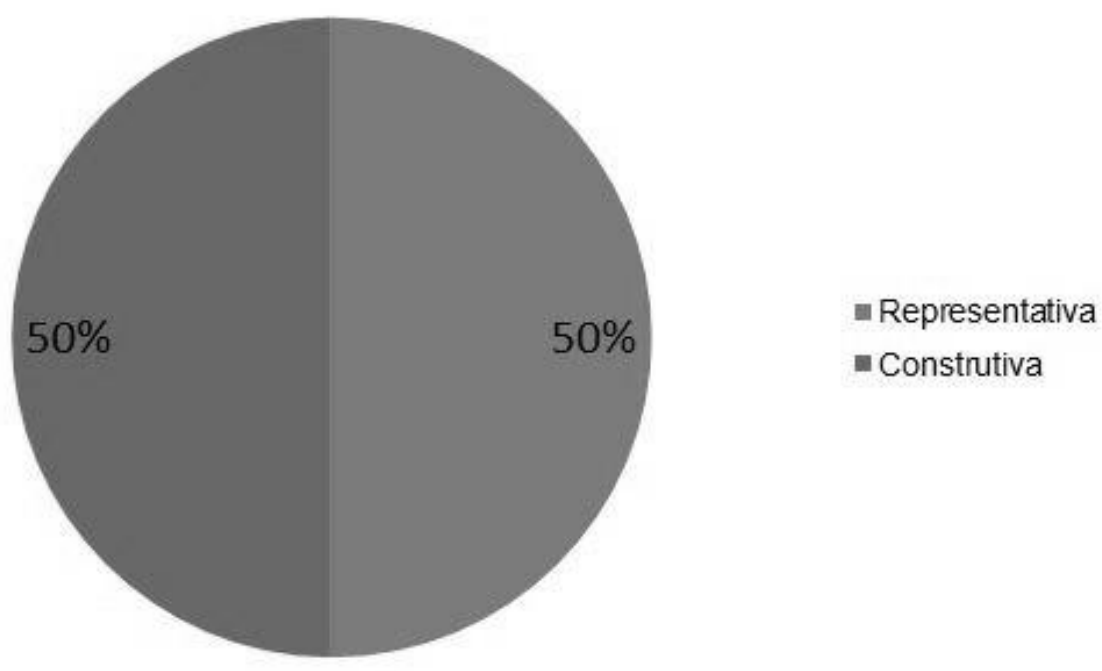

Gráfico 1 - Função Publicitária (Década de 70)

Este anúncio da Valisére (figura 1) utiliza elementos evidentemente expositivos na sua composição. Excluindo a assinatura ("Se eu fosse você só usava Valisére"), toda a linguagem verbal da peça está em torno de características do produto. Quer dizer, expõe o produto em seu formato real e explicita suas qualidades físicas, portanto pode ser classificada como representativa. 


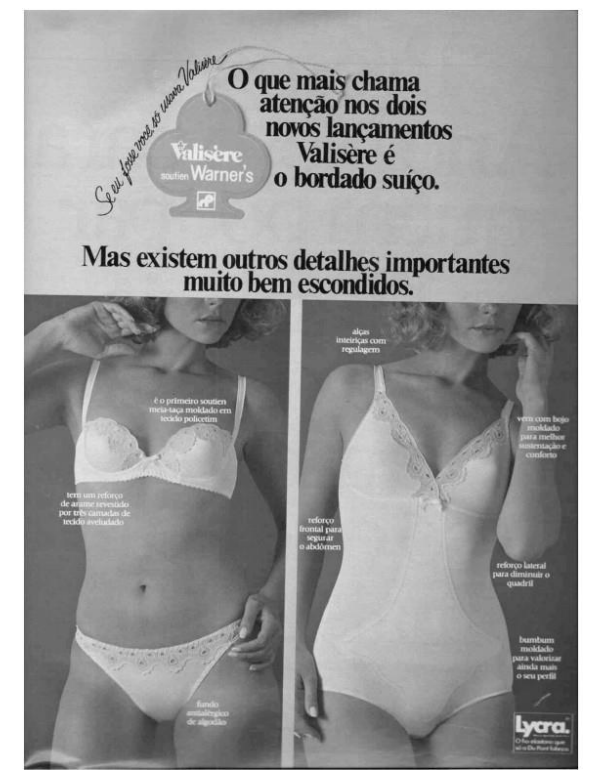

Figura 1 - Anúncio Valisére (Década de 70)

Já este anúncio da marca De Millus (figura 2) possui função construtiva, pois usa expressões com duplo sentido, misturando características da peça com sensações. Além de apresentar o produto, faz um apelo ao consumidor que não se restringe apenas ao consumo em primeira instância.

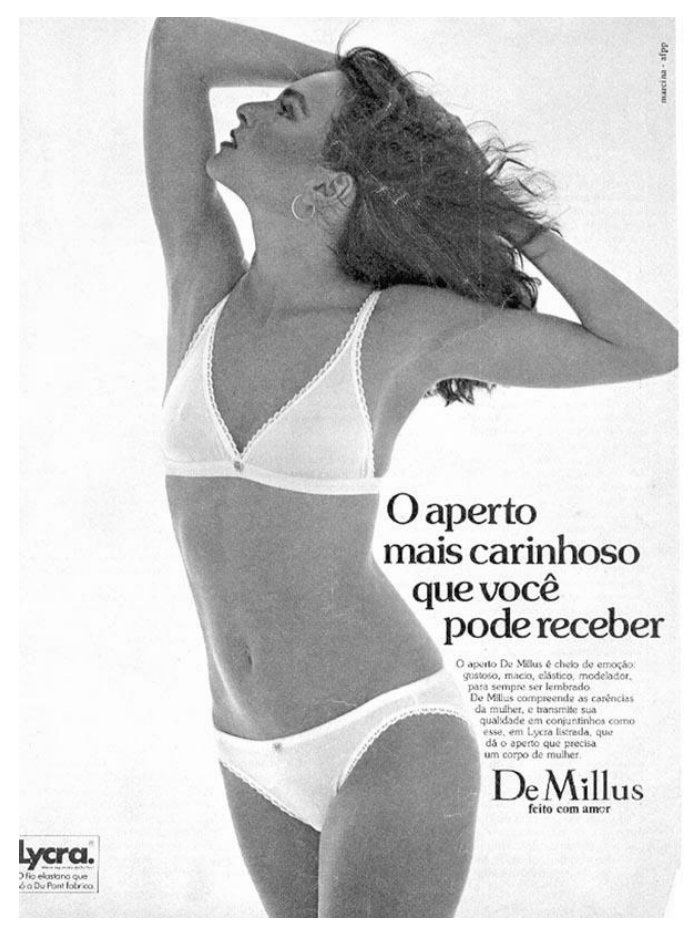

Figura 2 - Anúncio DeMillus (Década de 70)

A segunda categoria verificada se refere ao quadrado semiótico de Floch (2003) (Gráfico 2). 


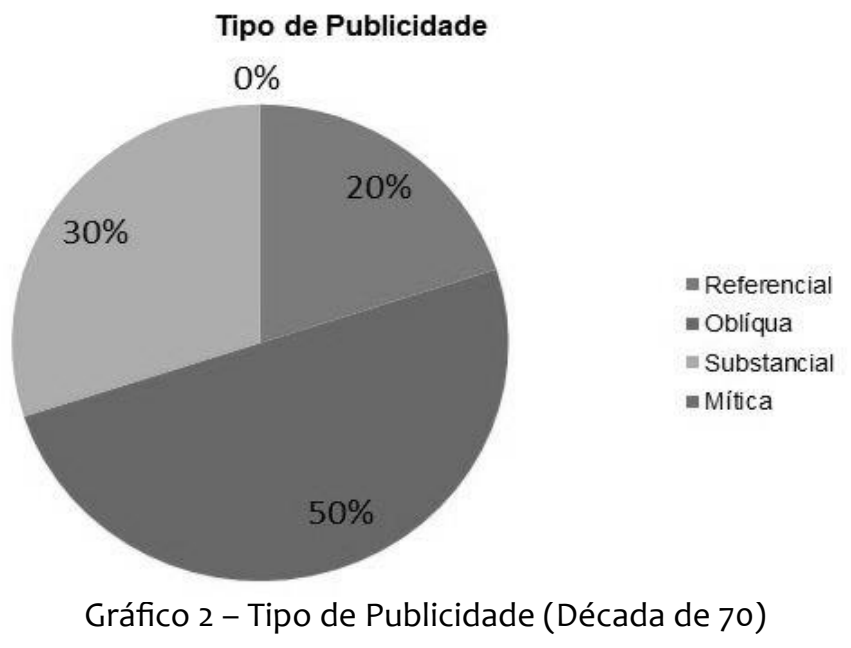

Das peças com função representativa, três foram classificadas como substanciais - apresentavam apenas a essência do produto, sem criar uma atmosfera que pudesse adicionar algum conteúdo (Figura 3) - e duas como referenciais - com um caráter demonstrativo e explicativo do produto (Figura 4).

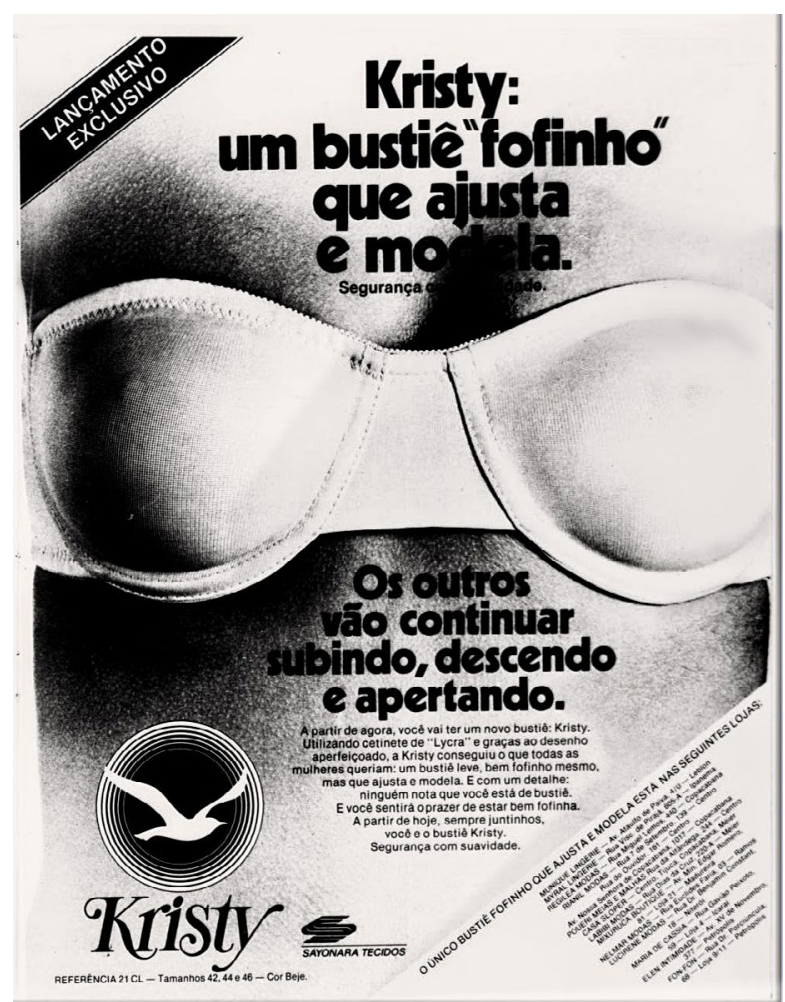

Figura 3 - Anúncio Kristy (Década de 70)

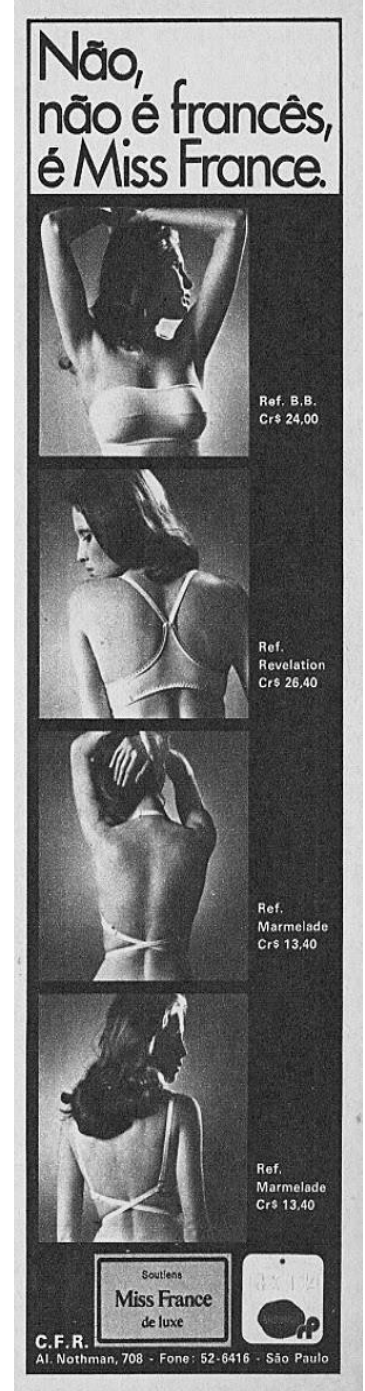

Figura 4 - Anúncio Miss France (Década de 70) 
Os anúncios construtivos foram todos classificados como oblíquos. Os cinco anúncios implicavam uma construção de sentido que dependia de uma interpretação do consumidor a partir de um referencial externo, como a influência que a marca tem no cenário da moda íntima no país (Figura 5). Palavras e formas foram usadas afim de construir esse sentido que estava implícito à comunicação, agregando um valor extra para o produto, além das suas características físicas.

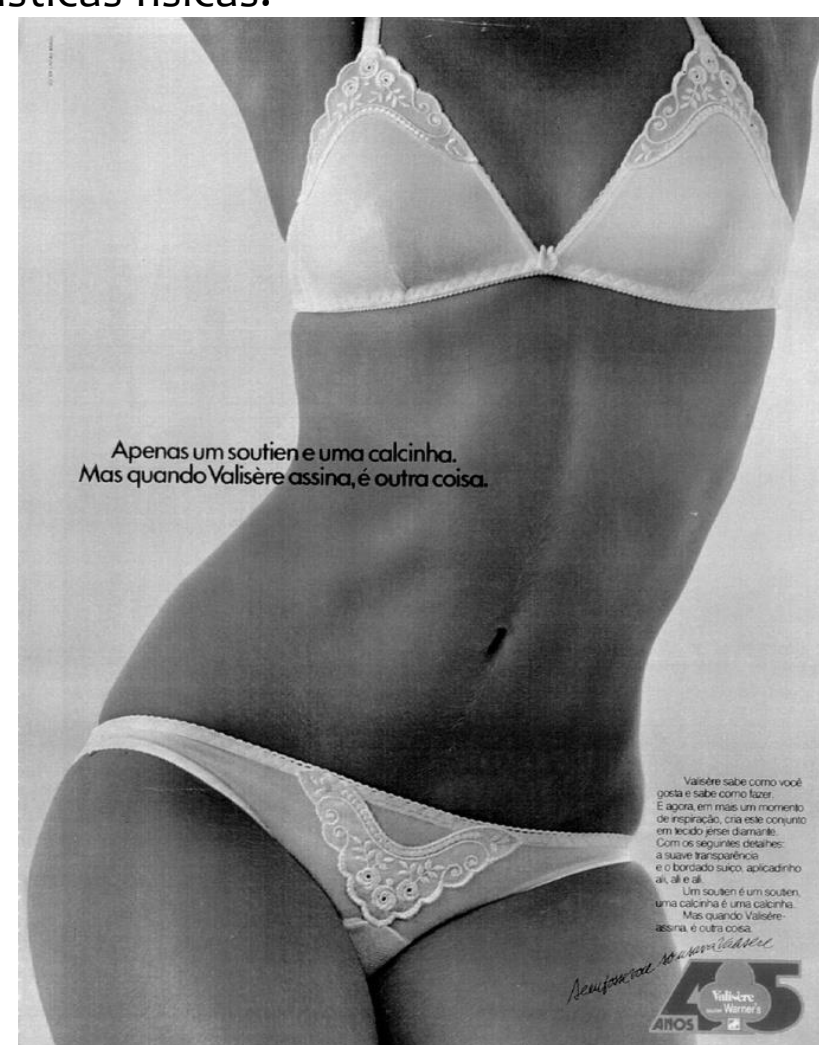

Figura 5 - Anúncio Valisére (Década de 70)

Observando a direção de sentido das peças (Gráfico 3), vê-se que todas se dirigiam às mulheres - o consumidor principal do produto.

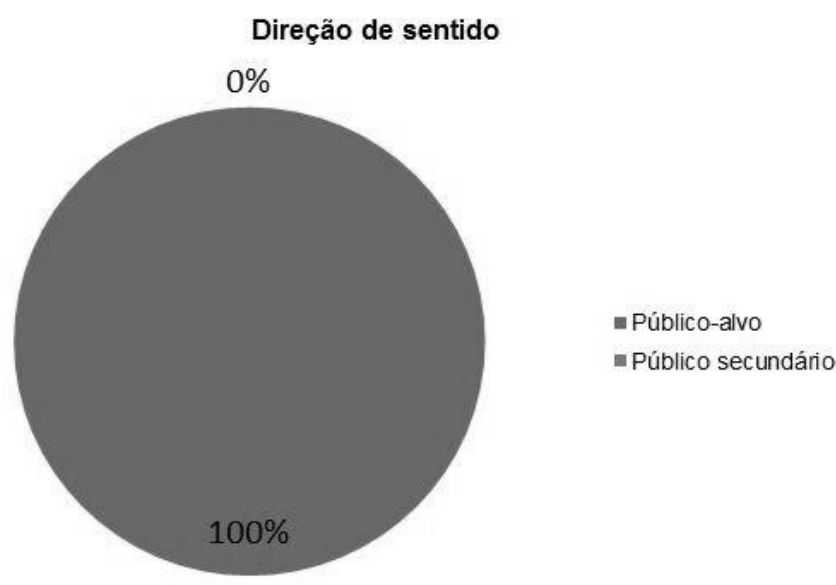

Gráfico 3 - Direção de sentido (Década de 70) 
Não havia a presença de nenhuma figura masculina nas fotografias e o texto sempre tinha a mulher como interlocutora, quando não era meramente explicativo das características do produto. Consequentemente, observamos que neste período a comunicação estava centrada na mulher e o bem estar com o seu corpo e conforto. Relações entre homens e mulheres, envolvendo a afetividade estão expostas de maneira sutil em algumas peças.

Quanto ao comportamento feminino o objetivo da análise era verificar se a publicidade estimulava a sensualidade ou ressaltava o conforto que $o$ uso do produto proporcionaria (Gráfico 4).

Representação Comportamental

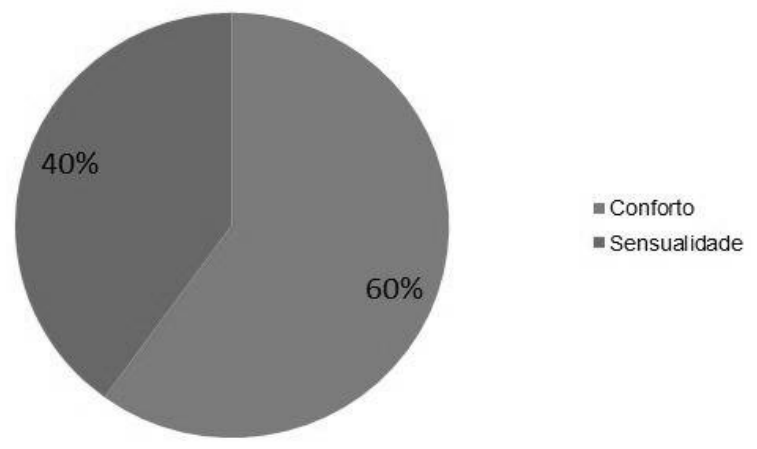

Gráfico 4 - Representação Comportamental (Década de 70)

Da amostra analisada, $60 \%$ dos anúncios possuem elementos que evidenciam o conforto e bem-estar como o principal estímulo de consumo. Consequentemente, estes anúncios mostram mulheres que buscam naquele produto a necessidade individual de bem-estar, como percebe-se na Figura 3, mostrada anteriormente. Os outros $40 \%$ apresentam elementos que evidenciam a sensualidade da mulher (Figura 6).

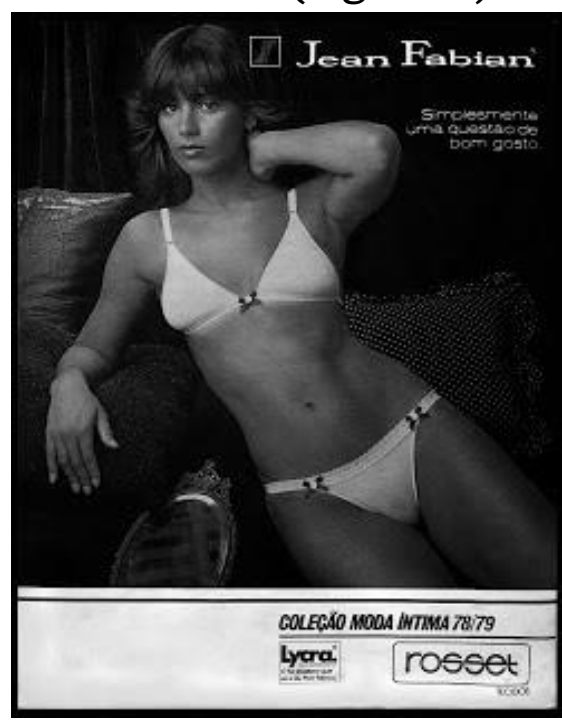

Figura 6 - Anúncio Jean Fabrian (Década de 70) 
Assim percebemos que nesta época o foco da representação feminina na publicidade de lingerie era o consumo do produto baseado nas suas características de resolução de uma necessidade primária: o conforto ao se usar roupas íntimas. Entretanto, a forma como a mulher é retratada fisicamente nas peças também tem influência sobre a imagem feminina que a publicidade estava difundindo nos anos 70. Podemos inferir a partir dos dados extraídos desta categorização que, neste período, as marcas de moda íntima focavam seu apelo comercial no uso prático, evidenciando o produto nas imagens. Relações afetivas entre homens e mulheres não eram abordadas abertamente e evitava-se identificar modelos, colocando o corpo como um utilizador do produto e a experiência de uso não era o centro da comunicação.

\subsection{Década de 1980: objeto de sedução}

Enquanto a década anterior mostrou-se mais direta e conservadora na publicidade de moda íntima, os anos 80 apresentaram uma linha criativa mais expressiva. Dentre a amostra selecionada para este período, $80 \%$ dos anúncios tem função construtiva (Gráfico 5), envolvendo elementos não explícitos e um contexto pra a construção do seu sentido, ou seja, percebe-se que as peças começaram a envolver um processo cognitivo mais complexo.

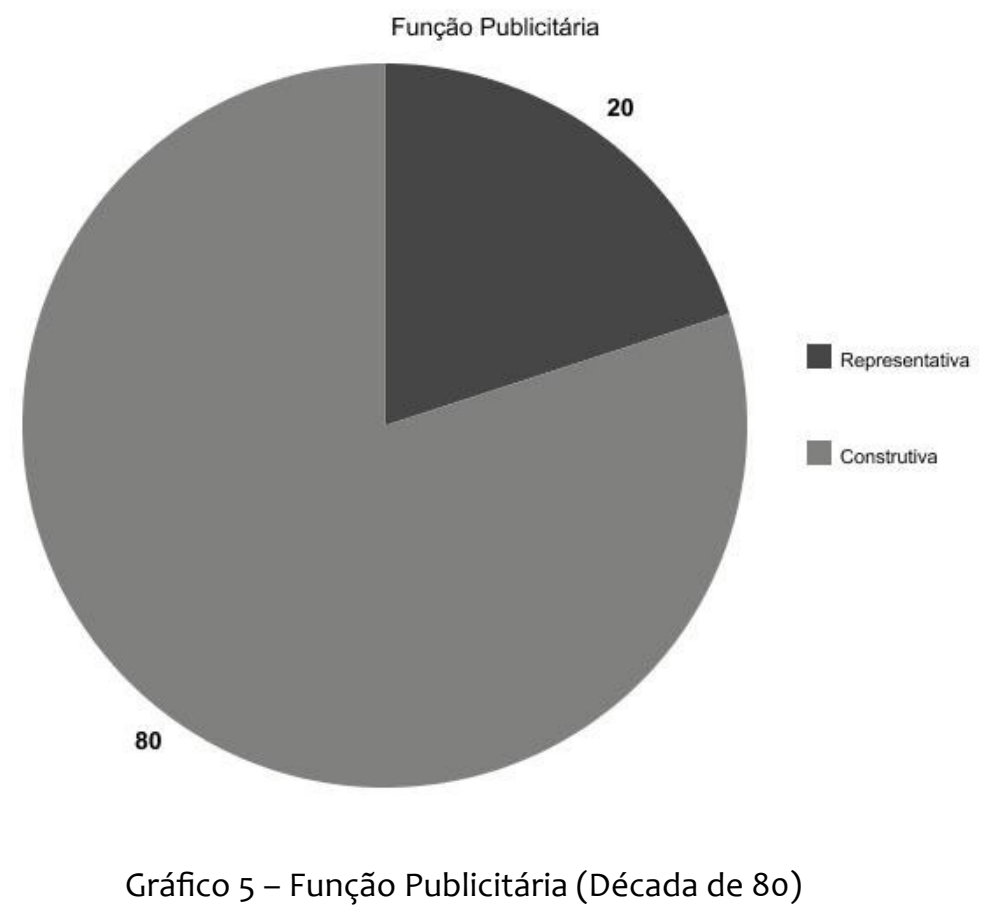

O anúncio da Valisére (Figura 7) é um exemplo de publicidade construtiva, pois o sentido é construído a partir da união cognitiva dos diversos elementos do anúncio: a diagramação, enquadramento da fotografia e texto. 


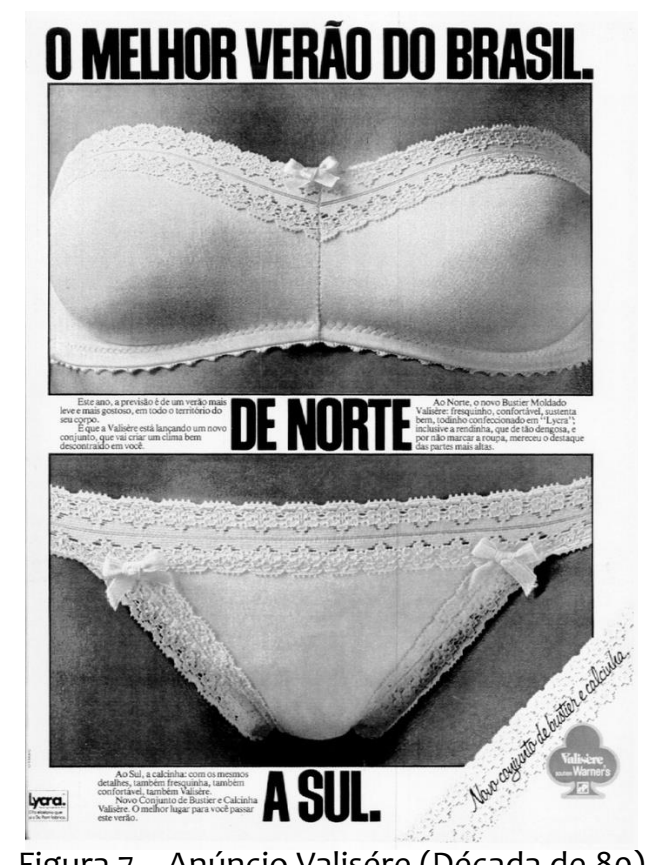

Na segunda categoria analisada percebe-se uma tendência muito diferente da observada na década anterior, conforme mostra o Gráfico 6. A maioria (60\%) dos anúncios foram classificados como míticos, agregando desejos e imaginação à representação do produto. O restante divide-se entre oblíquos, cujas relações provocadas exigem um referencial cognitivo, e substanciais, que apresentam o produto de forma direta. Neste período observamos que a tendência de representação do modo de uso já não é usada, pois nenhum anúncio enquadrou-se como referencial.

\section{Tipo de Publicidade}

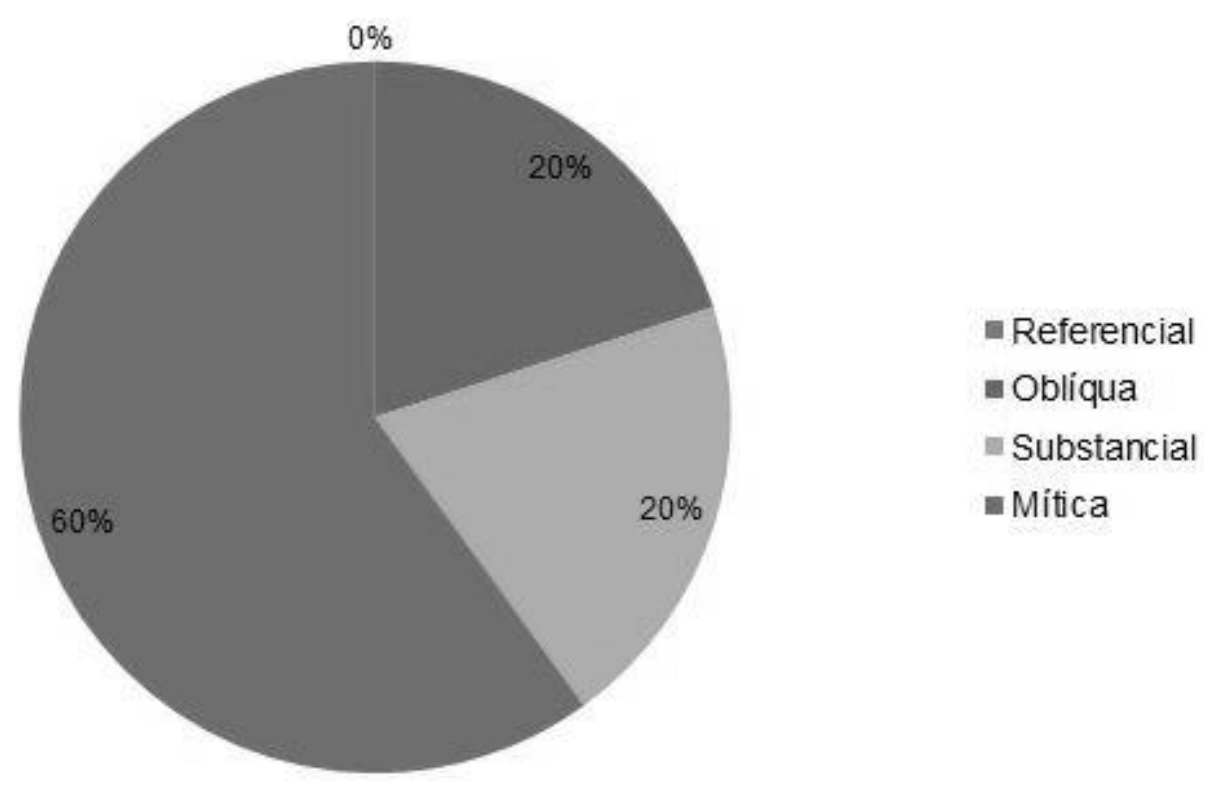

Gráfico 6 - Tipo de Publicidade (Década de 80) 
$\mathrm{Na}$ análise de direcionamento do sentido da comunicação, nota-se que nesta década algumas peças começam a incluir o sexo masculino como interlocutor (Gráfico 7).

\section{Direção de sentido}

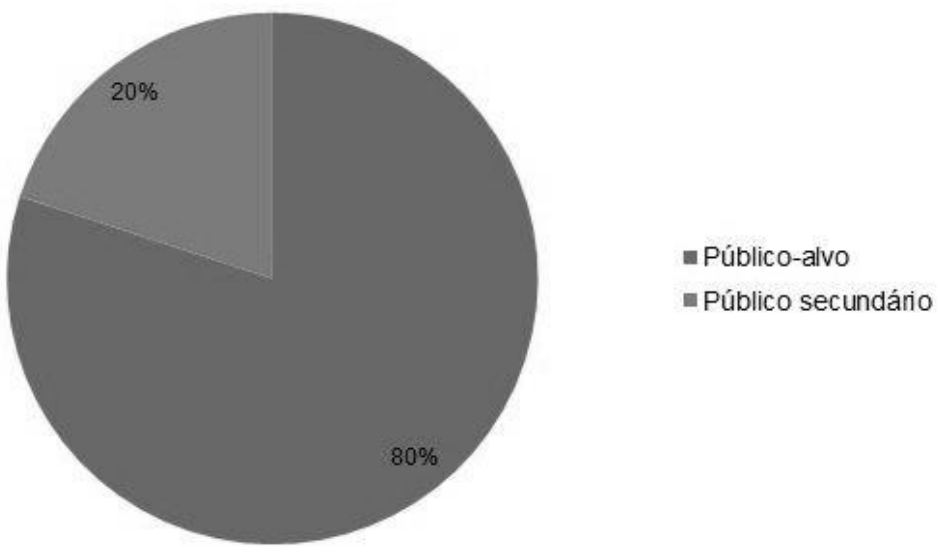

Gráfico 7 - Direção de sentido (Década de 80)

O anúncio da Valisére (Figura 8), que apresenta o texto "Rodrigo tratando do jardim de sua casa", é representativo dos anúncios que nesta década começam a mostrar o uso da lingerie com foco na sexualidade e relações afetivas.

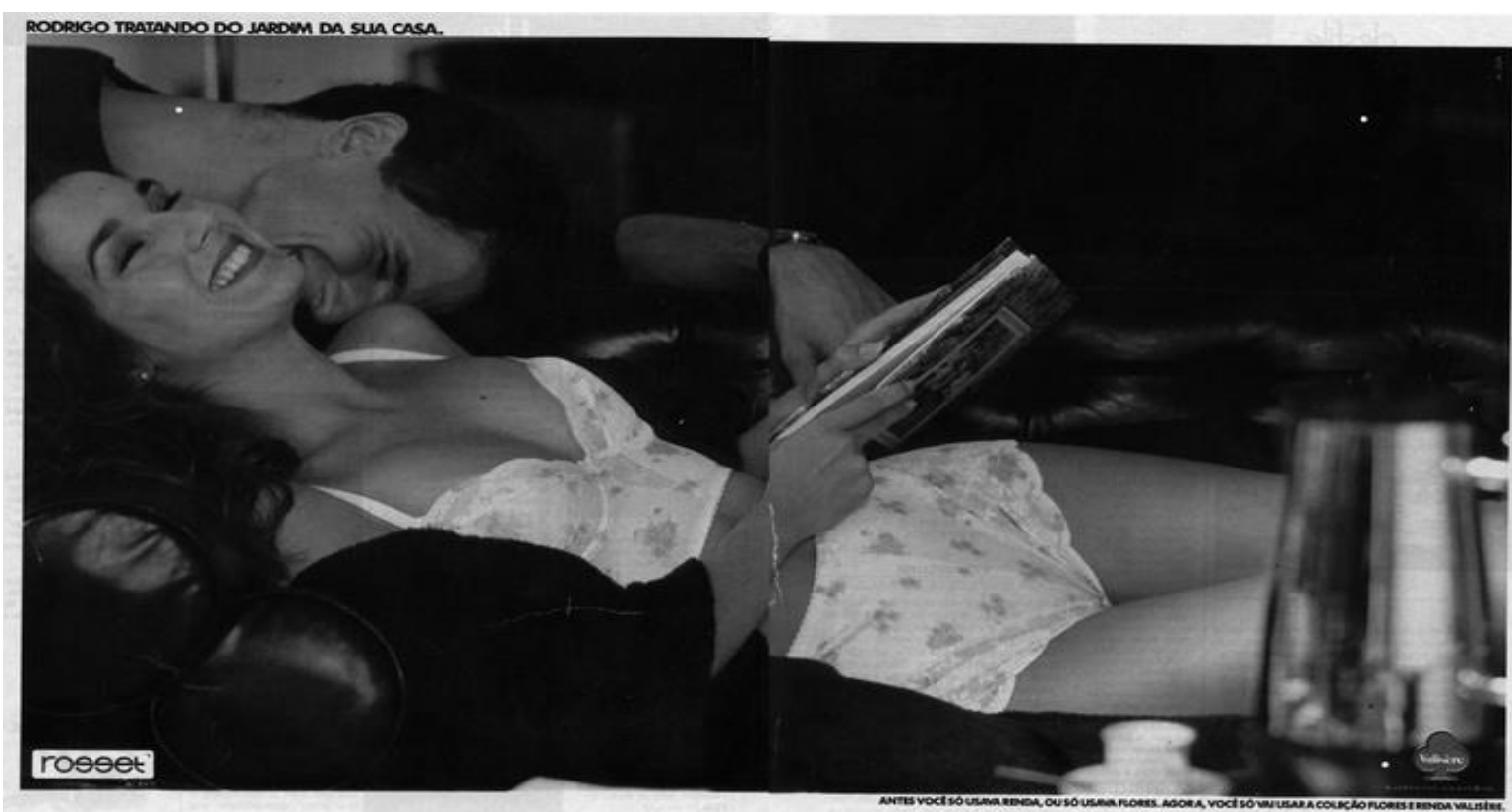

Figura 8 - Anúncio Valisére (Década de 80)

A distinção entre expressão de conforto ou de sensualidade nessa década também mostrou-se diferente da anterior. Em relação ao comportamento feminino, explicitado pela atitude da modelo nas fotografias, podemos perceber que $80 \%$ evidencia o apelo à sensualidade (Gráfico 8 ). 


\section{Representação Comportamental}

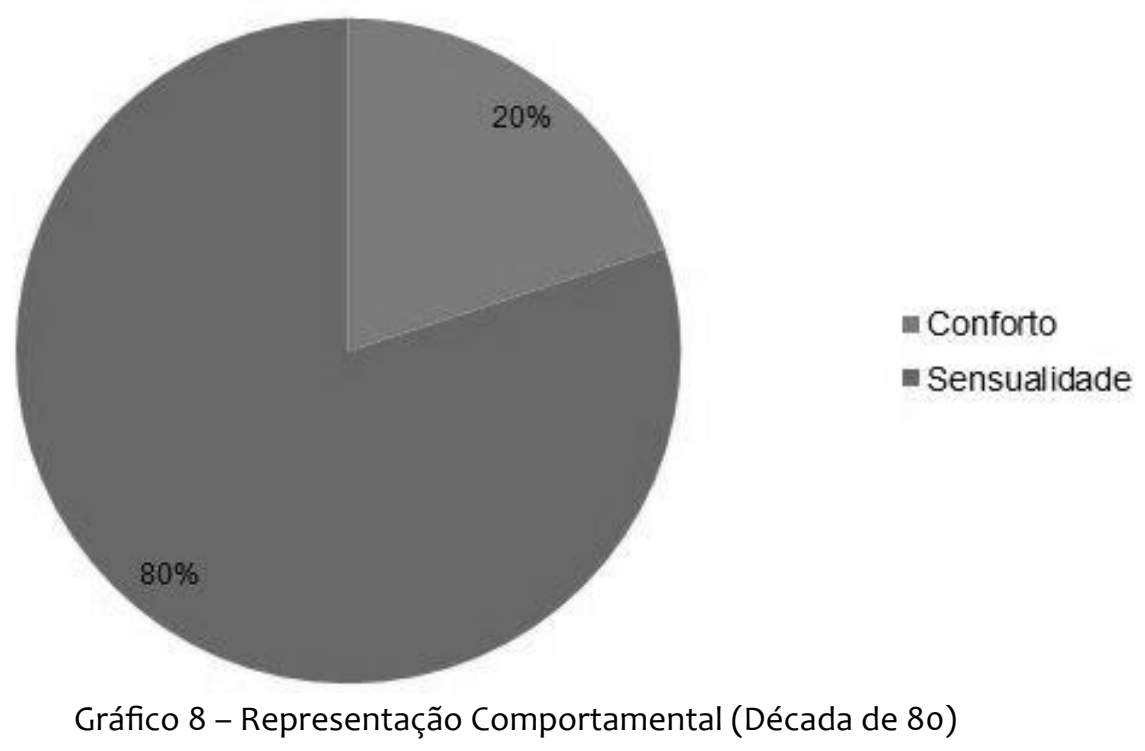

O anúncio da marca Valisére (Figura 9) sobre as "cuecas femininas" segue uma linha criativa diferente do que se observa na maioria dos anúncios desse segmento. Apesar do texto explorar uma questão a respeito da igualdade de gênero - "Valisére derruba o último privilégio dos homens" -, a imagem se contrapõe a ele. A pose e as expressões faciais das modelos denotam sensualidade e indicam uma construção direcionada ao público masculino.

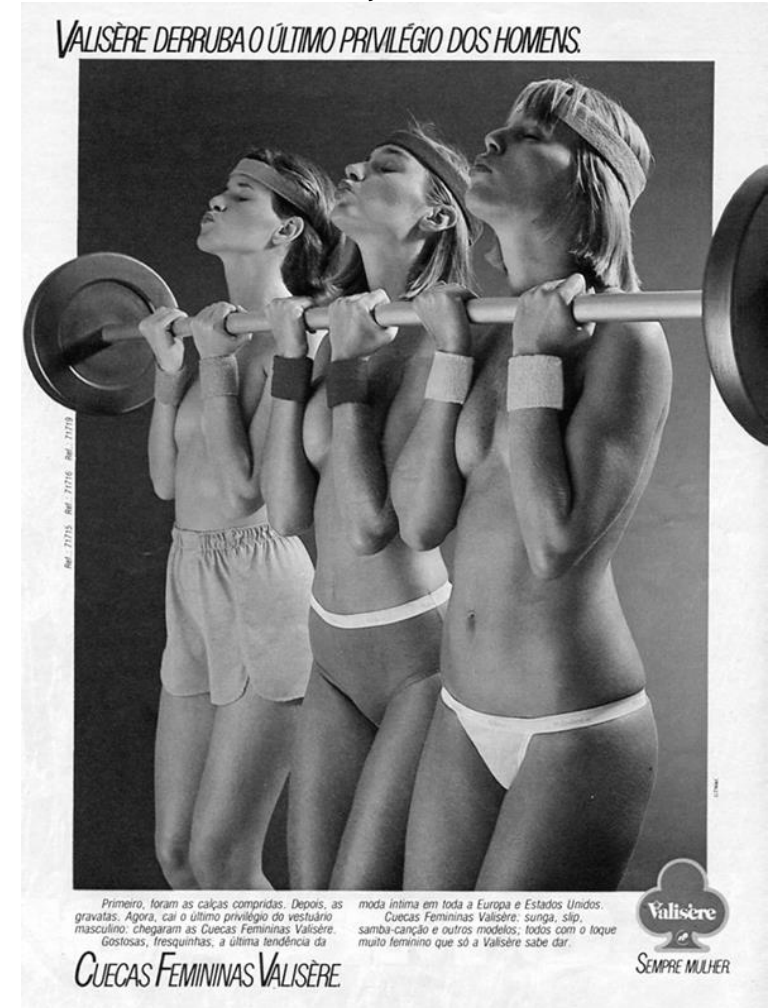

Figura 9 - Anúncio Valisére (Década de 80) 
A década de 80 inovou no que diz respeito à linha criativa dos anúncios de lingerie. Entretanto, os anúncios apresentaram um apelo muito maior à sensualidade, a lingerie não foi mais anunciada em vistas ao conforto da consumidora, mas como objeto representativo da relação afetiva entre homens e mulheres.

\subsection{Década de 1990: em busca da atenção masculina}

Na década de 1990 nota-se que novas marcas começaram a ser comercializados no país, porém, apresentam uma homogeneidade no apelo comercial dos anúncios. Todas as peças do período apresentaram a função construtiva (Gráfico 9), muito mais que anteriormente, o texto por vezes é o protagonista da peça e a imagem não tem tanto a dizer quanto o diálogo estabelecido com o interlocutor.

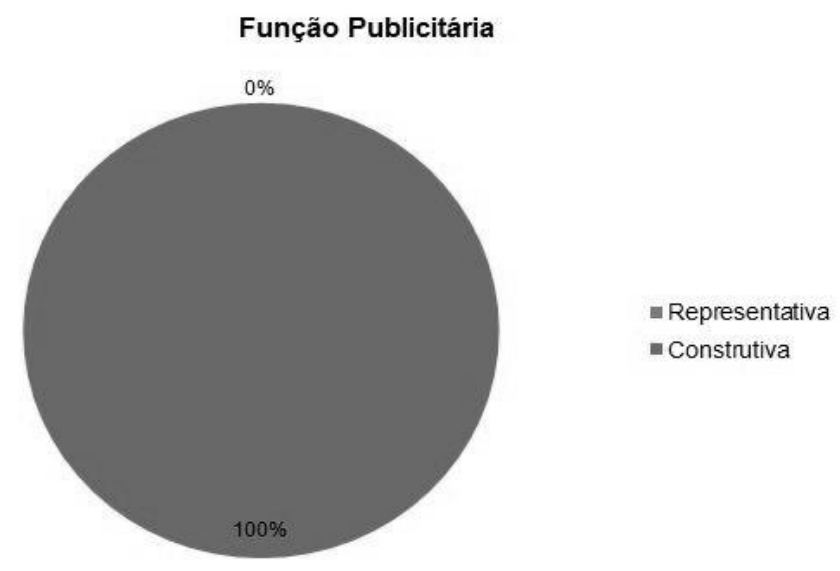

Gráfico 9 - Função Publicitária (Década de 90)

Quanto ao tipo de publicidade, foram encontradas somente anúncios oblíquos (80\%) e míticos (20\%) (Gráfico 10). Este resultado era esperado, uma vez que nenhuma peça apresentou a função representativa, característica dos anúncios referenciais e substanciais.

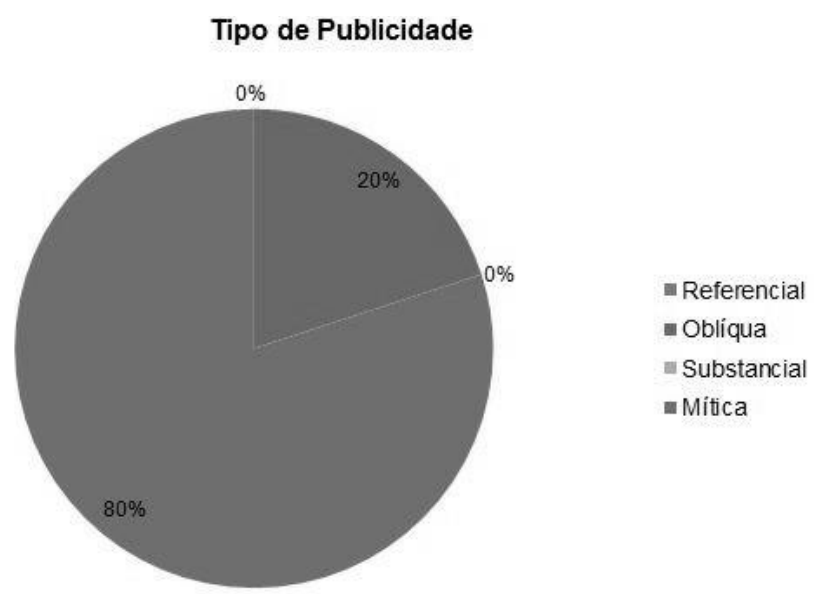

Gráfico 10 - Tipo de Publicidade (Década de 90) 
Seguindo uma tendência observada a partir da década de 80, o imaginário do leitor começou a ser acionado mais frequentemente, dando espaço à construção de cenários e situações, através do uso de textos, cores e composições, conforme percebe-se na Figura 10.

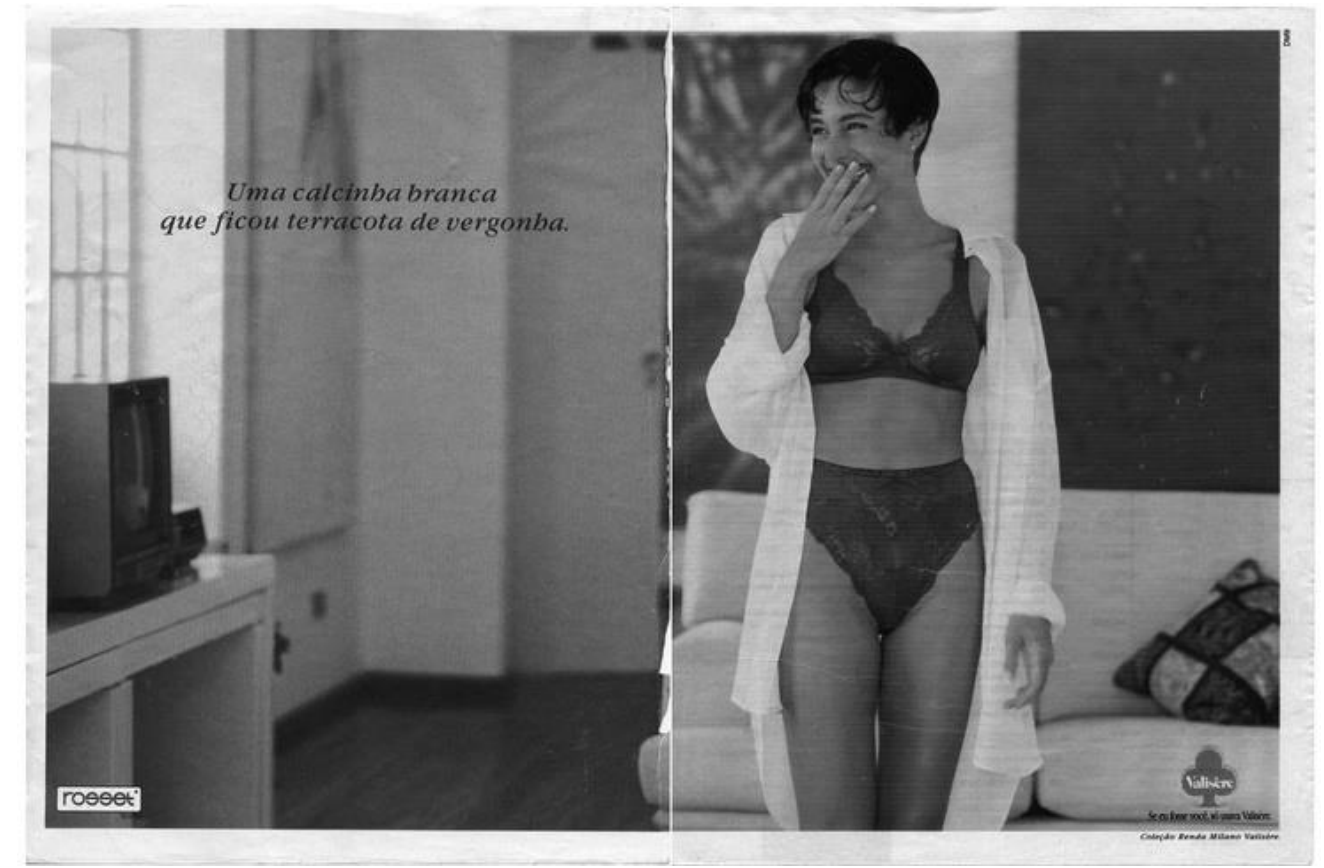

Figura 10 - Anúncio Valisére (Década de 90)

Quanto à representação da figura feminina nos anúncios, observamos que a grande maioria das peças selecionadas dirigia seu discurso ao público feminino - target principal do segmento (Gráfico 11).

\section{Direção de sentido}

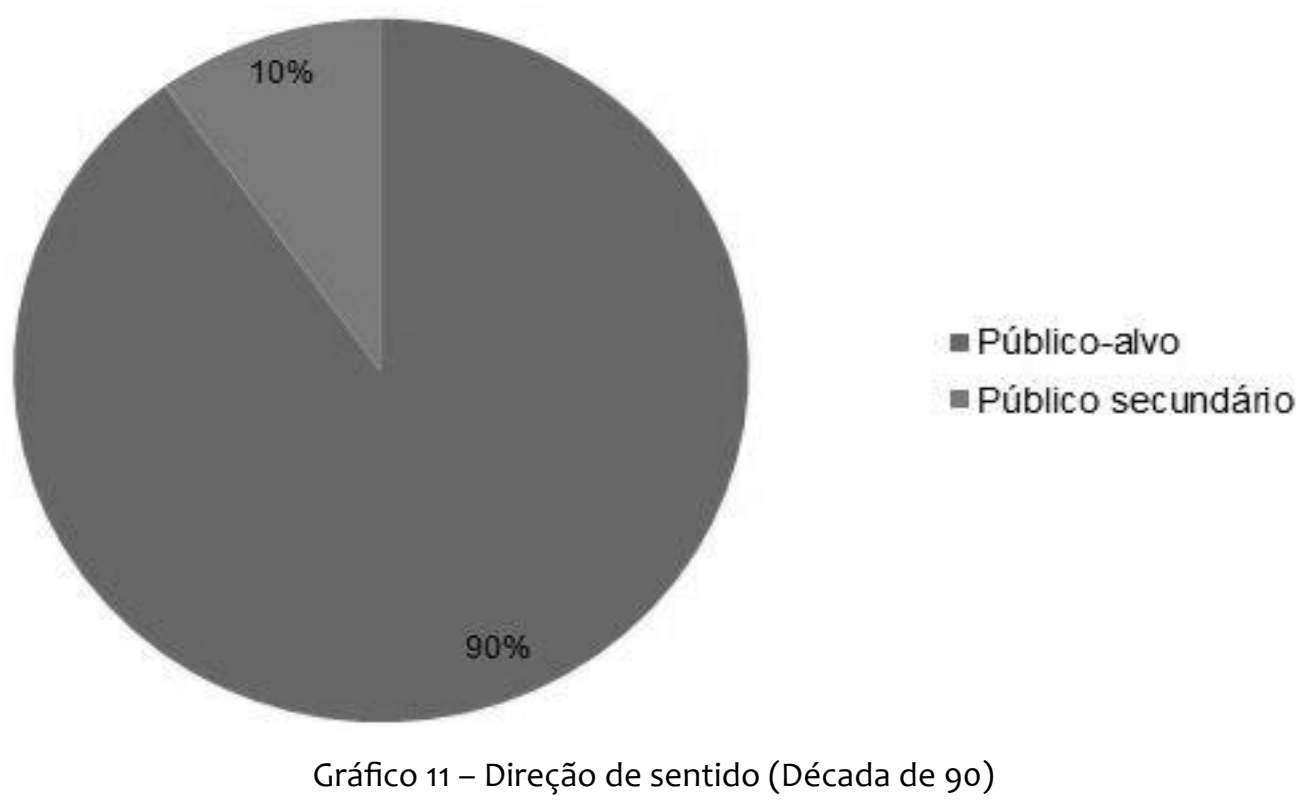


Apenas um dos anúncios apresenta uma comunicação dirigida ao público masculino como interlocutor principal (Figura 11). O texto "Não recomendado para cardíacos" refere-se exclusivamente às emoções dos homens.

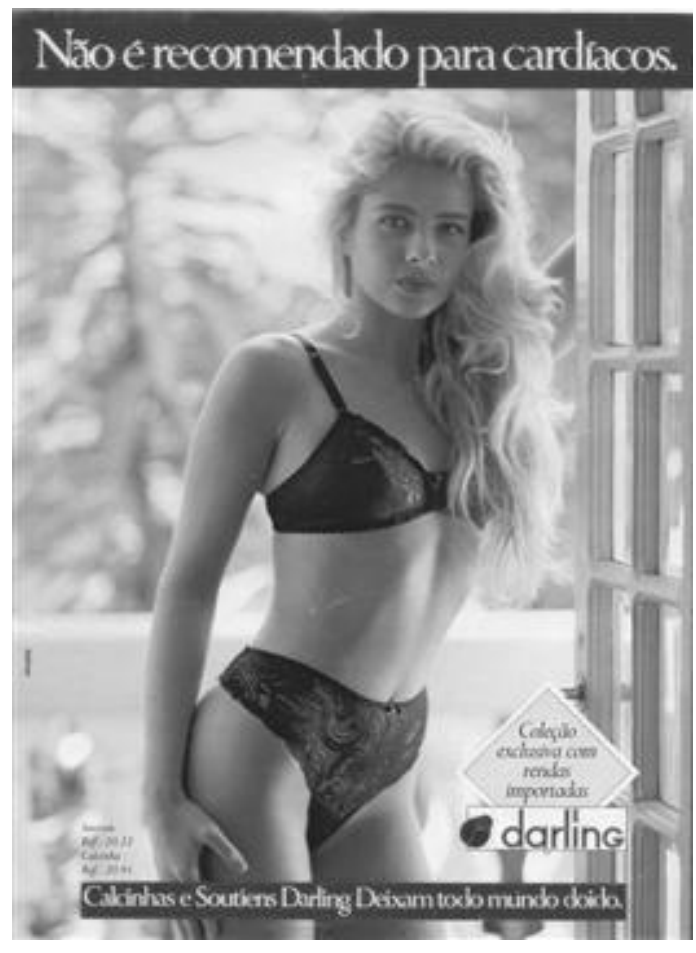

Figura 11 - Anúncio Darling (Década de 90)

Nas demais peças, ainda que o discurso não fosse dirigido ao homem, ele seguia sendo tratado como uma motivação para utilização do produto, conforme exemplifica a Figura 12.

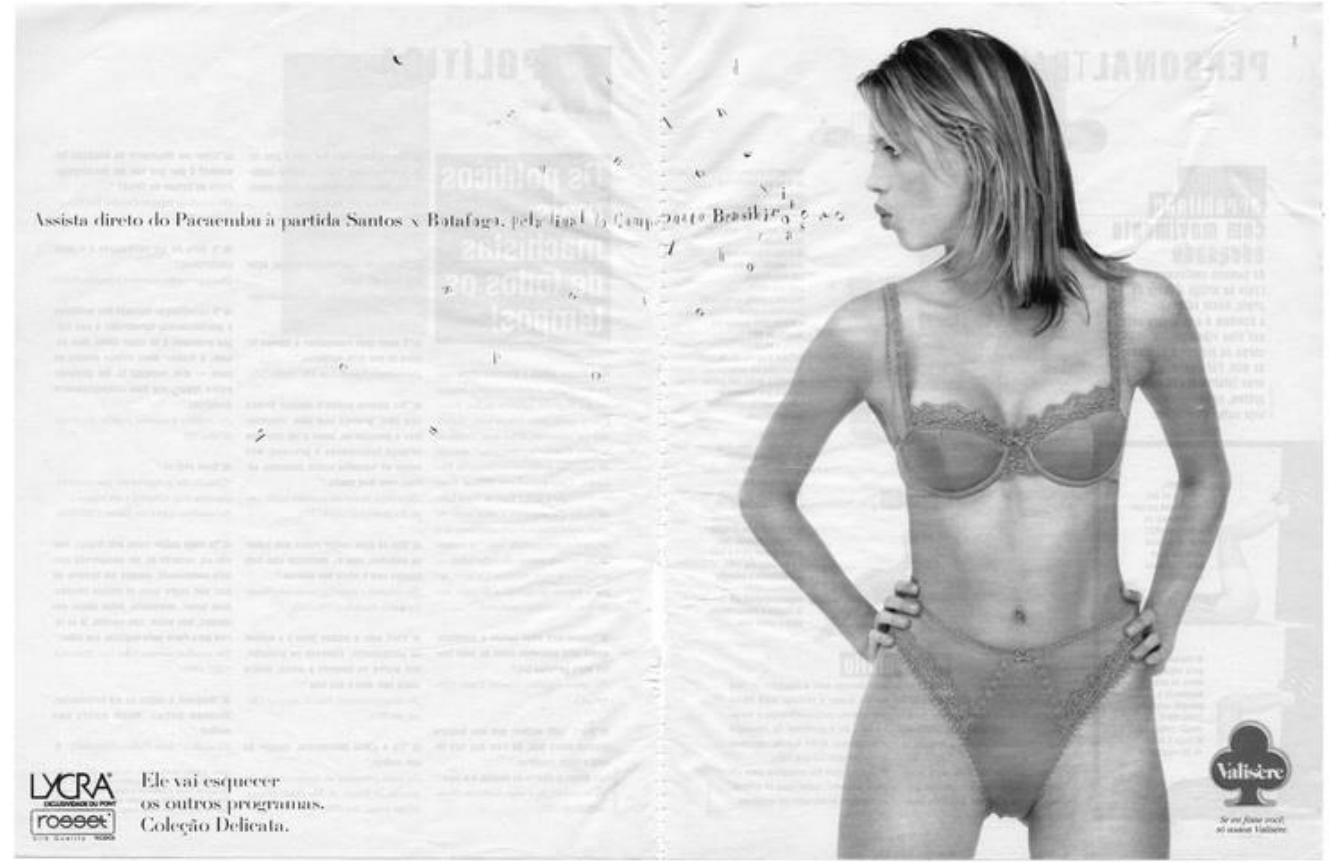

Figura 12 - Anúncio Valisére (Década de 90) 
A quarta categoria nos dá sinais sobre o apelo mais utilizado pelas marcas e mostra que na década de 1990 a tendência se manteve na representação da sensualidade da mulher (Gráfico 12).

Representação Comportamental

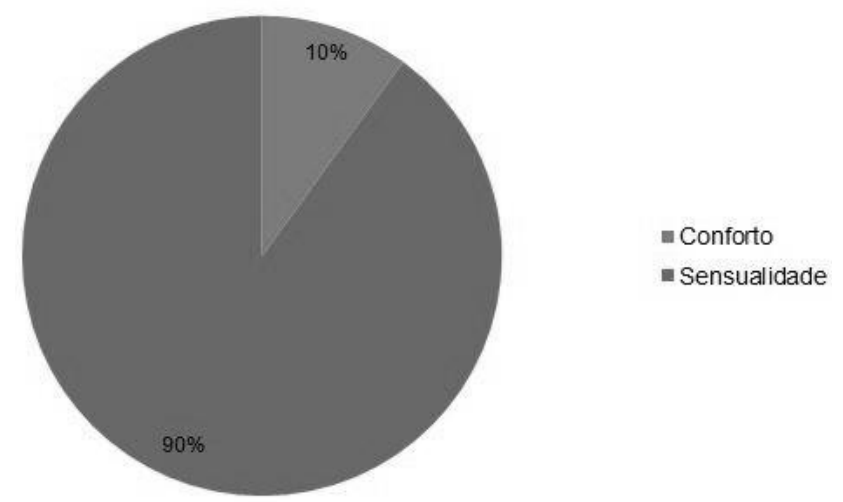

Gráfico 12 - Representação Comportamental (Década de 90)

Em apenas um caso o conforto ou a relação de bem-estar com o próprio corpo foi evidenciada, em todos os demais a mulher é representada como objeto a ser observado/admirado pelo sexo oposto. No anúncio acima (Figura 12) a mulher é colocada lado-a-lado com uma manchete sobre futebol, com a qual compete pela atenção masculina. O produto é apresentado como solução para que essa atenção seja conquistada.

Nesta década foi possível notar também o uso de personalidades como porta-vozes dos produtos (Figura 13), tendência que irá se consolidar nas décadas seguintes.

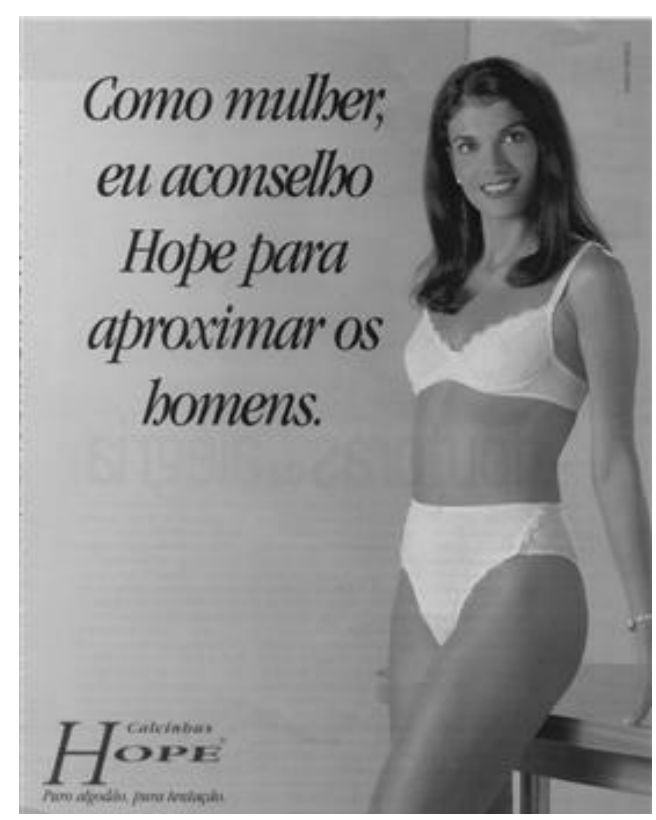

Figura 13 - Anúncio Hope (Década de 90) 


\subsection{Década de 2000: a volta da função representativa}

A chegada do século XXI trouxe consigo algumas mudanças na construção da mensagem publicitária no segmento de moda de roupa íntima. A partir dos anos 2000, a maioria dos anúncios começou a seguir o padrão de construção "imagem + assinatura". Essa tendência é observada até os dias de hoje. Os anúncios com essa formação mais simples, geralmente não envolvem a construção de um sentido, apenas apresentam o produto, sem referenciar um contexto e sem necessitar uma interpretação cognitiva do consumidor.

Observa-se também que ocorreram mudanças na função publicitária dos anúncios. Na década anterior, as peças eram essencialmente construtivas. Nos anos 2000 encontramos peças que voltaram a ter o caráter representativo, que foram mais comuns na década de 70 e começaram a ter uso reduzido a partir dos anos 80 . Neste período, metade dos anúncios selecionados apresentaram função construtiva e a outra metade função representativa (Gráfico 13).

Função Publicitária

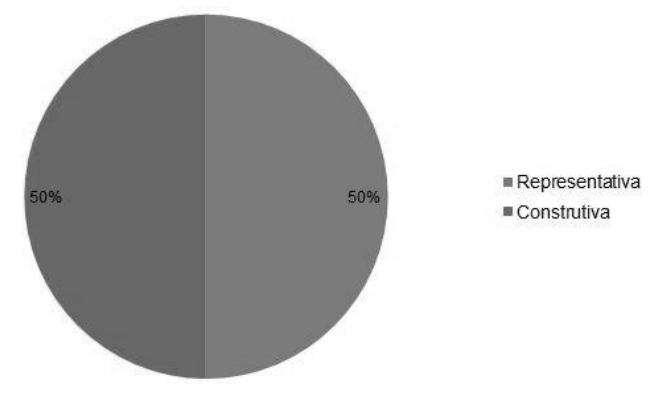

Gráfico 13 - Função Publicitária (Década de 2000)

Quanto ao tipo publicitário, constatou-se que a maioria (50\%) das peças pode ser considerada como substancial, reforçando o padrão criativo de utilização somente de foto e assinatura. $O$ restante das peças divide-se em míticas (40\%) e oblíquas (10\%) (Gráfico 14).

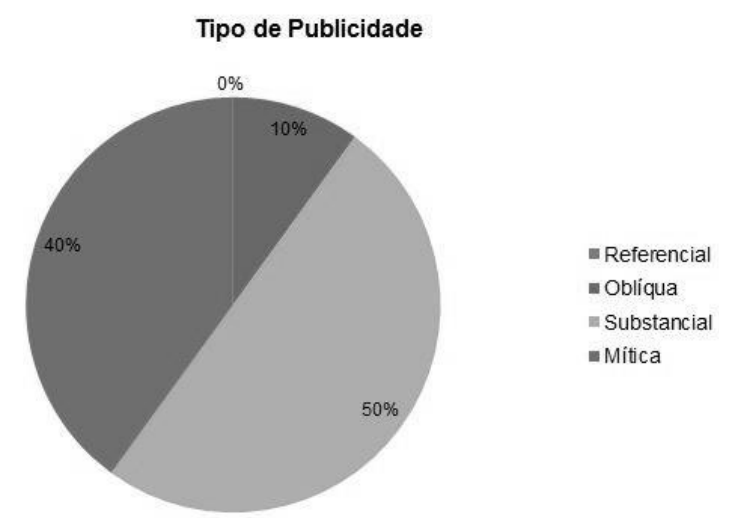

Gráfico 14 - Tipo de Publicidade (Década de 2000) 
Um exemplo de publicidade oblíqua é o anúncio da linha antibacteriana da Valisére, que ainda que não tenha a função de criar uma atmosfera ou cenário como os anúncios míticos, utiliza seu texto para relacionar propriedades do produto que serão interpretadas pelo consumidor quando aliadas a outro referencial, construindo assim o sentido da propaganda (Figura 14).

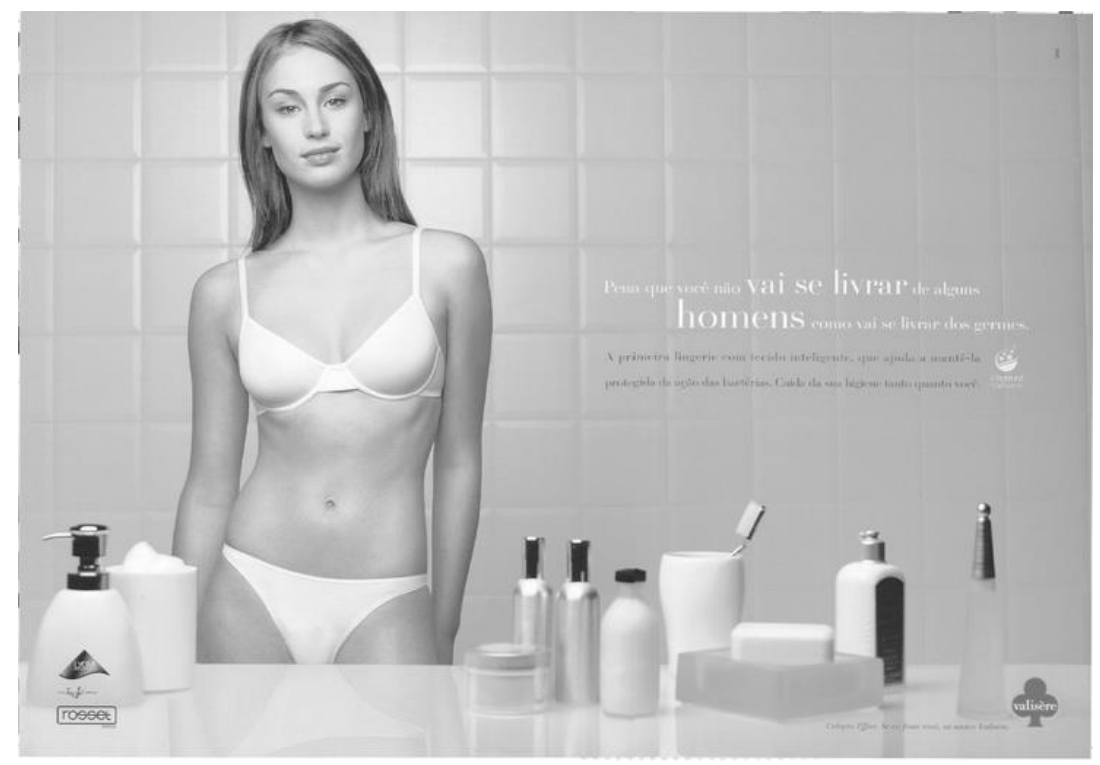

Figura 14 - Anúncio Valisére (Década de 2000)

Todos os anúncios deste período direcionam seu texto para a mulher (Gráfico 15). Entretanto, pode-se inferir ao analisar o diálogo com a interlocutora, que a figura masculina está presente constantemente. A exemplo do que foi observado na década anterior, o uso do produto está fortemente atrelado com questões afetivas.

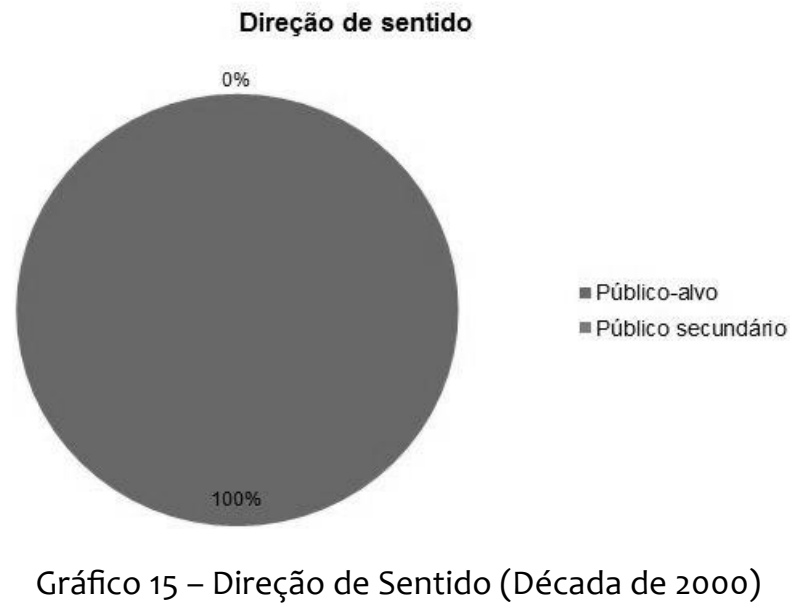

Entretanto, pode-se inferir ao analisar o diálogo com a interlocutora, que a figura masculina está presente constantemente. A exemplo do que foi observado na década anterior, o uso do produto está fortemente atre- 
lado com o relacionamento da mulher com o sexo masculino, conforme o anúncio abaixo, da marca Recco (Figura 15).

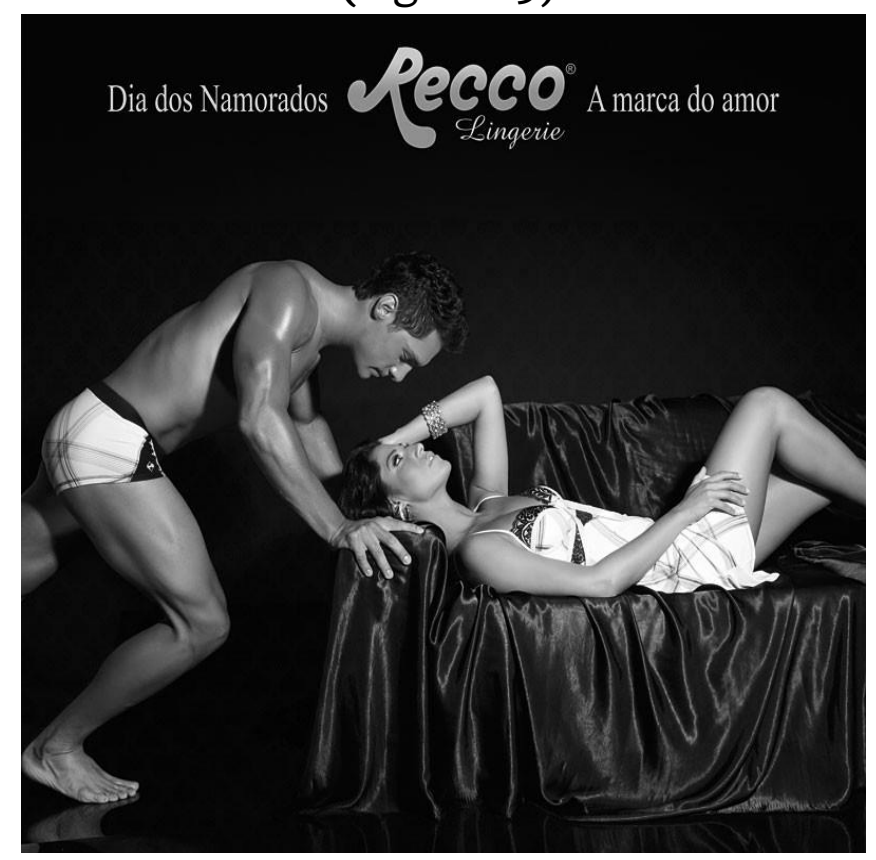

Figura 15 - Anúncio Recco (Década de 2000)

Quanto à representação comportamental da figura feminina o Gráfico 16 mostra que, assim como na década anterior, a maioria das peças utiliza o apelo da sensualidade (80\%), como é exemplo a Figura 16.

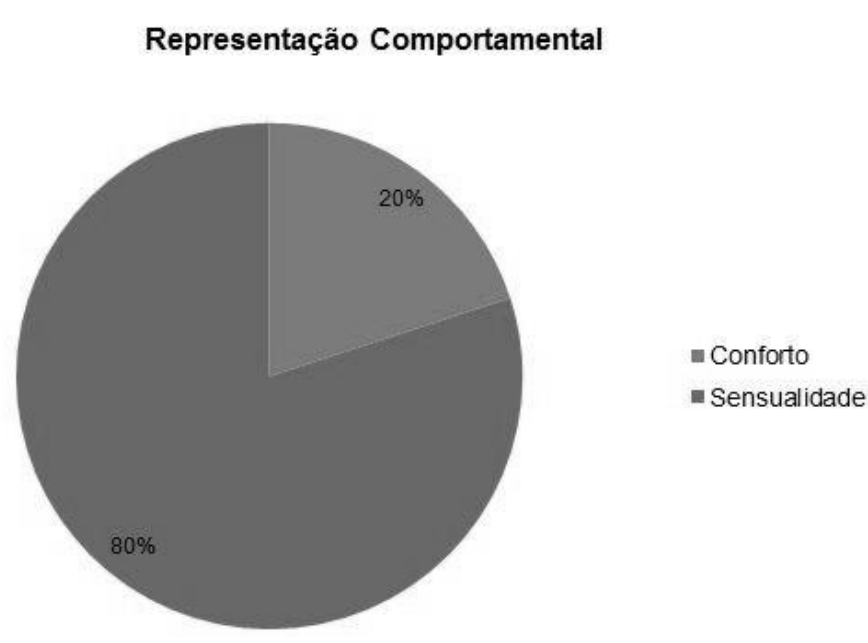

Gráfico 16 - Representação Comportamental (Década de 2000)

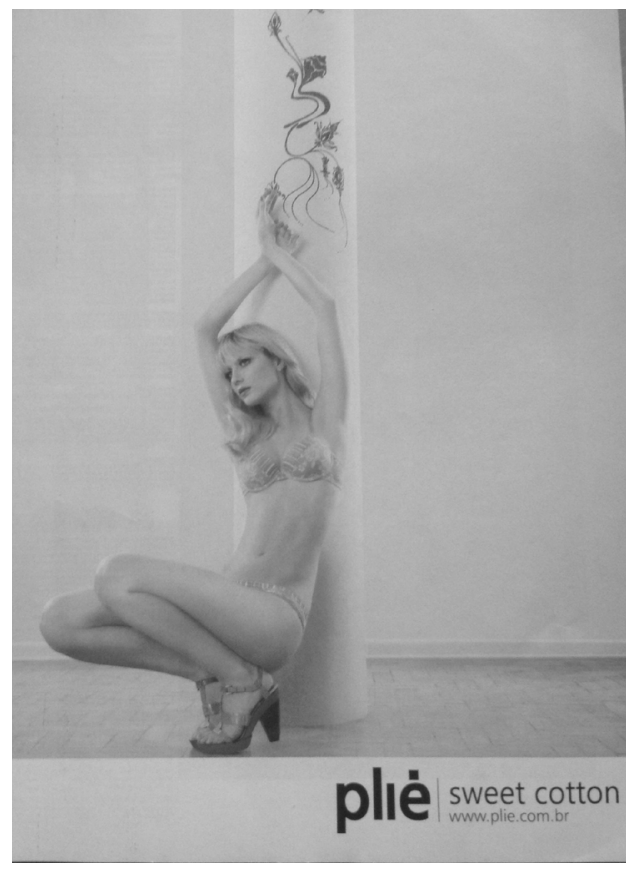

Figura 16 - Anúncio Plié (Década de 2000) 


\subsection{Década de 2010: nada de novo no front}

Finalizando a análise temporal dos anúncios, seguimos com a análise das peças dos últimos anos, que representam a tendência atual de construção publicitária para o ramo da moda íntima. Percebe-se que muito do que foi consolidado na última década como padrão publicitário continua a ocorrer atualmente. Será possível observar a semelhança entre as construções do conteúdo dos anúncios desde o início do século XXI.

Quanto à função publicitária, exatamente como nos dez anos anteriores, metade da amostra possui função construtiva e a outra metade com função representativa (Gráfico 17).

Função Publicitária

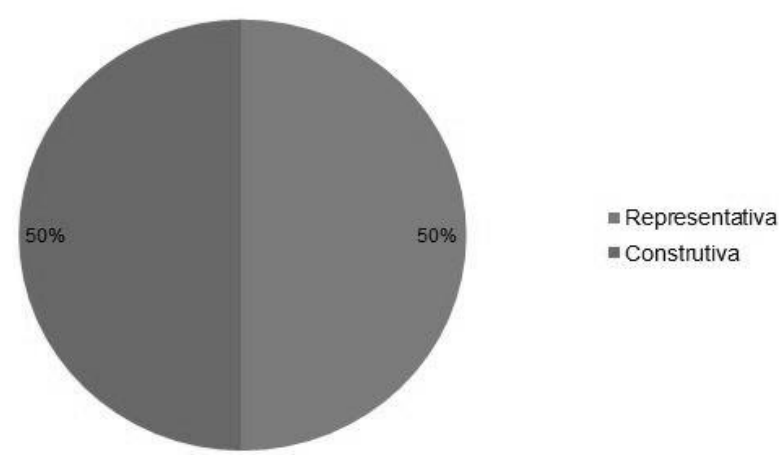

Gráfico 17 - Função Publicitária (Década de 2010)

O padrão de criação que consiste em fotografia e assinatura continua frequente, ilustrando a categoria representativa, no qual nenhuma mensagem há de ser construída.

Todas as peças construtivas apresentaram-se como oblíquas (Gráfico 18), ou seja, incitavam a construção de um sentido a partir de elementos da peça unidos com elementos cognitivos do consumidor.

Tipo de Publicidade

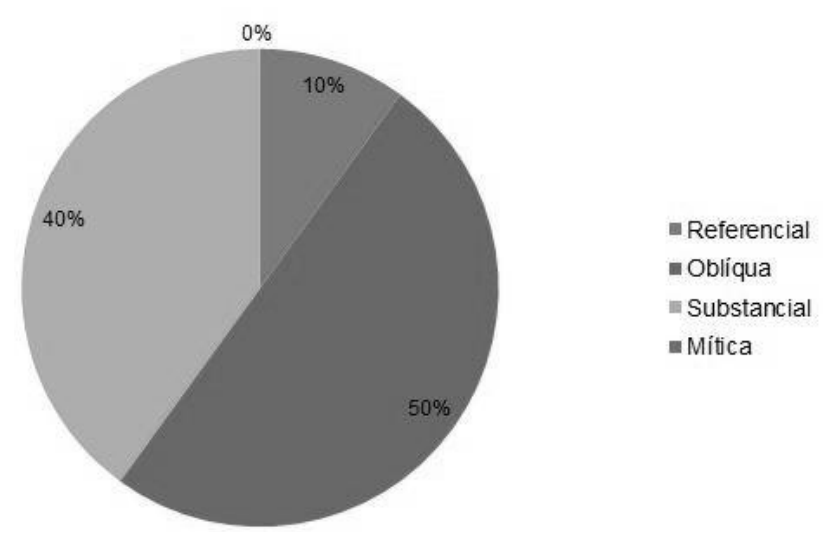

Gráfico 18 - Tipo de Publicidade (Década de 2010) 
As peças referenciais dividem-se em substancias (40\%) - aqui se encaixam todos os anúncios que seguem o padrão de formação fotografia e assinatura, expondo o produto em destaque, sem tanta preocupação com a atmosfera construída - e referenciais, com somente um caso registrado ( Figura 17) que explora as características técnicas do produto e formas de uso.

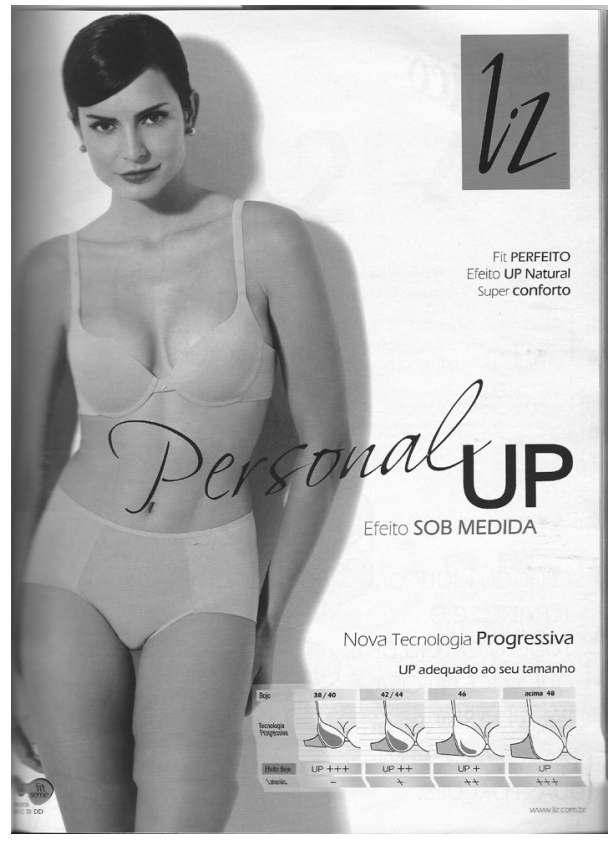

Figura 17 - Anúncio Liz (Década de 2010)

Quanto à direção do discurso dos anúncios, esta década tem se configurado como locutora para o público-alvo majoritário das marcas - o feminino. Apenas uma das peças colhidas na amostra tem seu diálogo estabelecido de forma diferente, trazendo o homem como um dos beneficiados pelo produto (Gráfico 19).

\section{Direção de sentido}

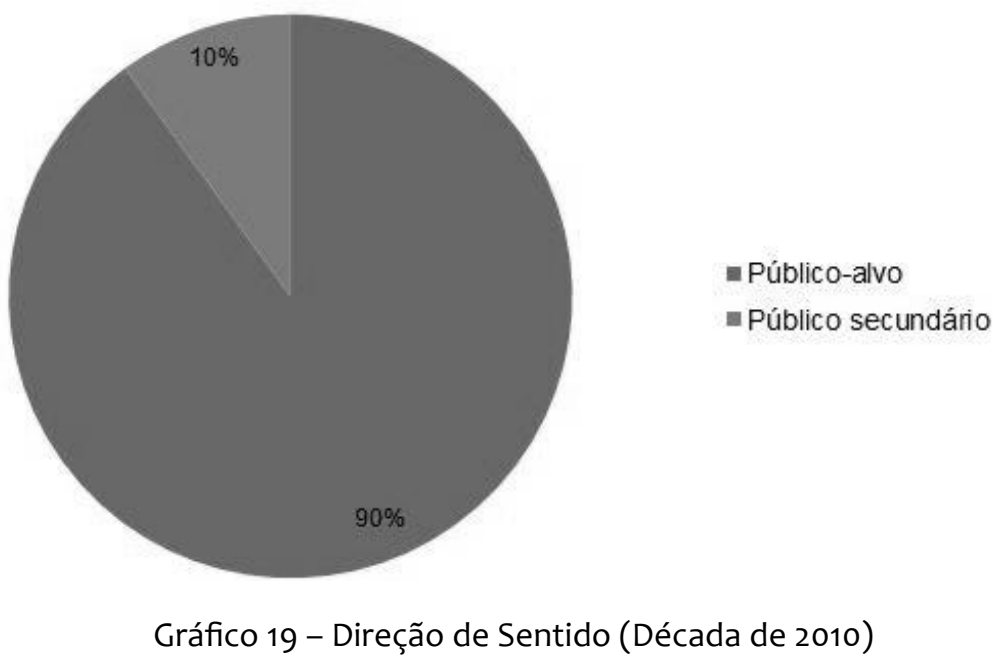


Analisando a representação do comportamento feminino nos anúncios da amostra (Gráfico 20), temos um resultado igual ao da década anterior: $80 \%$ dos anúncios remetem à ideia de sensualidade e $20 \%$ transmitem a sensação de conforto, ou pelo menos não priorizam a imagem sensual do corpo feminino, apenas representam uma forma de utilização neutra pela modelo.

Representação Comportamental

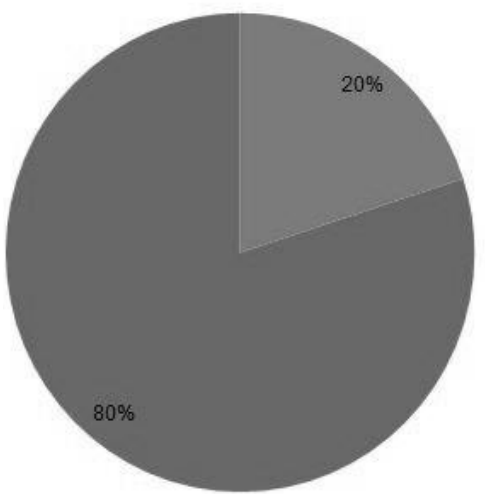

- Conforto

- Sensualidade

Gráfico 20 - Representação Comportamental (Década de 2010)

Interessante notar que é cada vez mais comum o uso de atrizes, modelos e outras celebridades no anúncio de moda íntima. Um exemplo é o anúncio da marca Gisele Bundchen Intimates (Figura 18), cujas peças publicitárias são ilustradas pela própria dona da marca. Apesar de não objetificar o corpo da mulher, o anúncio traz um ideal de forma física que já é atrelado à imagem da modelo no mundo da moda como um todo. Isso pode gerar um afastamento ou distorção da imagem passada pela mídia do corpo feminino às consumidoras que têm biotipos variados.

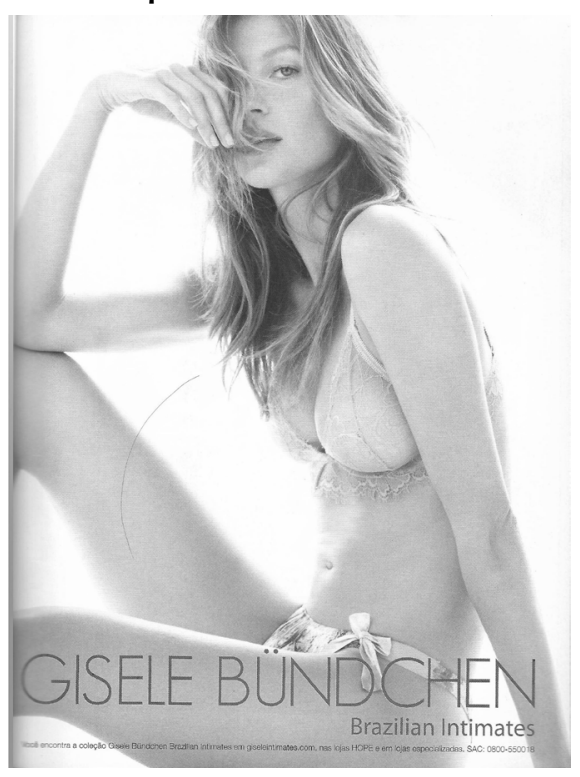

Figura 18 - Anúncio Gisele Bündchen Intimates (Década de 2010) 


\section{CONSIDERAÇÕES}

Analisadas de forma linear, as características dos anúncios publicitários de lingerie revelam mudanças em alguns aspectos da representação do feminino na publicidade.

A década de 70 apresentava equilíbrio quanto à formação da mensagem publicitária nos referenciais semióticos. No que tange à representação da mulher, estava muito conectada com o conforto e com a relação de uso prático do produto, a sexualidade ainda não era utilizada de forma expressiva nos argumentos de venda das marcas deste período. Foi no final desta década que as insatisfações quanto à representação do gênero feminino nos meios culturais começaram a tomar força dentro do movimento feminista, pautando muitas das discussões das décadas seguintes.

Nos anos 80, as peças começaram a envolver muitos outros elementos e seu sentido passou a se configurar majoritariamente como construtivo. A maioria das peças foi classificada como mítica, incorporando um contexto de uso ao produto: não era mais a lingerie que estava sendo vendida, mas toda uma experiência de consumo. Neste período a segunda onda do feminismo estava nos seus momentos iniciais, trazendo à esfera pública todas as discussões sobre a sexualidade feminina e sua representação na cultura. $\mathrm{Na}$ publicidade de moda íntima percebe-se que alguns reflexos desta nova forma de encarar a sexualidade estavam sendo abordados, com sutileza, visto que ainda eram poucos os grupos sociais que já haviam incorporado esta mudança de valores e que aceitavam aceitando novas formas de pensar.

Em linhas gerais, esta década começou a apresentar mudanças no que tange a representação do uso do produto pela mulher, mas ainda liga a utilização do produto à relação conjugal da consumidora. Por mais que a sexualidade começasse a ser abordada de forma mais aberta, a mulher não era tratada de forma independente e sim ligada ao seu parceiro. Era de se esperar que a mulher começasse a ter uma representação mais independente neste período, visto que o movimento feminista estava em seu auge, após um período de incubação, com grandes conquistas na esfera política, principalmente. Porém, a questão das reivindicações feministas estava em pauta na sociedade, mas ainda era tratada como algo alheio à realidade da mulher brasileira.

Na década de 90 foi reforçada a tendência do uso do relacionamento conjugal como argumento de venda. A presença da figura masculina tor- 
nou-se constante, seja por meio da fotografia ou por menções no diálogo. Nos anos 90 o movimento feminista já estava consolidado como instituição na esfera pública e pequenas formas de manifestação populares estavam se formando, dentro de bairros e associações, e apresentava as questões da violência contra a mulher como centro das reivindicações. Ou seja, há então uma disparidade entre as mensagens que circulavam no meio social: enquanto havia uma luta expressiva contra os casos de violência doméstica e independência da mulher no que se refere ao seu corpo, as propagandas de roupa íntima incentivavam o uso do produto do corpo feminino como ferramenta central nas relações conjugais.

Com a chegada do século XXI, a construção da mensagem publicitária mudou de forma e passou a seguir o padrão de foto e assinatura, evitando diálogos e construções elaboradas de contextos e cenários. Entretanto os últimos 14 anos têm a particularidade de terem intensificado o uso de personalidades famosas - atrizes e modelos - como porta-vozes das marcas. Apesar de este período ter reduzido o uso de apelos conjugais nas mensagens de venda - não os eliminando completamente - a representação da mulher enquanto pessoa "comum" foi prejudicada. Corpos impecáveis, de pessoas com prestígio artístico, fama e fortuna trouxeram um distanciamento entre a imagem feminina transmitida pelas marcas e a realidade do seu público-alvo. A questão de aceitação do corpo feminino, da refutação dos padrões de beleza ditados pela mídia tem sido amplamente discutida em blogs, em redes sociais e nas manifestações mais informais do movimento feminista.

Portanto, percebe-se que a mensagem publicitária - em propagandas de lingerie, especificamente - não caminha em consonância com os discursos que circulam em outros canais de comunicação no que se referem às questões de representação do feminino. Ainda que existam marcas que utilizam argumentos diferenciados em suas comunicações, demonstrando que estão a par das tendências do movimento feminista, a maioria das marcas segue valorizando e incentivando o culto ao corpo. Assim, o cenário atual demonstra que ainda que as questões comportamentais estejam sendo abordadas de modo mais próximo às discussões do movimento feminista; as questões da representação corporal ainda são marcadas por uma distância entre os discursos da publicidade e o do movimento feminista. 


\section{REFERÊNCIAS}

BUITONI, D. Mulher de papel: a representação da mulher pela imprensa feminina brasileira. São Paulo, SP: Summus Editorial, 1981.

COSTA, A. A. O Movimento Feminista no Brasil: Dinâmicas de Uma Intervenção Política. 2004. 20f. Instituto Universitario de Estudios de la Mujer da Universidad Autonoma de Madrid. Madrid. 2004.

FLOCH, J. M. Alguns conceitos fundamentais em semiótica geral. São Paulo, SP: Centro de Pesquisas Sociossemióticas, 2001.

GREIMAS, A. J. Semântica Estrutural. São Paulo, SP: Cultrix, 1979.

PINTO, C. R. J. Uma história do feminismo no Brasil. São Paulo, SP: Editora Fundação Perceu Abramo, 2003.

RIZZOTTO, C. C. Quinto poder? Características, objetivos e estratégias discursivas dos observatórios feministas de mídia. 2013. 288 f. Tese (Doutorado em Comunicação e Linguagens) - Universidade Tuiuti do Paraná. Curitiba, PR, 2013.

SARTI, C. A. $O$ início do feminismo sob a ditadura no Brasil: o que ficou escondido.

Trabalho apresentado no XXI Congresso Internacional da LASA (Latin American Studies Association), Chicago, 1998. Disponível em: < http://lasa.international.pitt.edu/LASA98/ Sarti.pdf >. Acesso em: 20 mai. 2014.

\section{Dascale Muller}

Aluna do curso de graduação em Comunicação Social - Publicidade e Propaganda da Universidade Federal do Paraná. E-mail: dascale_muller@hotmail.com.

\section{Carla Candida Rizzotto}

Doutora em Comunicação e Linguagens pela Universidade Tuiuti do Paraná. Professora visitante do Programa de Pós-Graduação em Comunicação da Universidade Federal do Paraná, com bolsa do programa PNPD/Capes. E-mail: carla_rizzotto@yahoo.com.br. 
